\title{
Bioaccumulation of Fluoride in Plants and Its Microbially Assisted Remediation: A Review of Biological Processes and Technological Performance
}

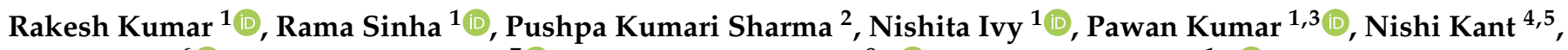 \\ Aprajita Jha ${ }^{6} \mathbb{D}$, Prakash Kumar Jha ${ }^{7} \mathbb{D}$, Pankaj Kumar Gupta ${ }^{8, * \mathbb{D}}$, Prabhakar Sharma ${ }^{1, *(\mathbb{D} \text {, }}$ \\ Rakesh Kumar Singh ${ }^{2}$, Rajeev Pratap Singh ${ }^{9} \mathbb{D}$, Ashok Ghosh ${ }^{10,11} \mathbb{D}$ and P. V. Vara Prasad ${ }^{7}$ (D)
}

Citation: Kumar, R.; Sinha, R.; Sharma, P.K.; Ivy, N.; Kumar, P.; Kant, N.; Jha, A.; Jha, P.K.; Gupta, P.K.; Sharma, P.; et al. Bioaccumulation of Fluoride in Plants and Its Microbially Assisted Remediation: A Review of Biological Processes and Technological Performance. Processes 2021, 9, 2154. https://doi.org/ $10.3390 /$ pr9122154

Academic Editors: Clarisse Brigido and Paulo Ivan Fernandes-Júnior

Received: 26 October 2021

Accepted: 26 November 2021

Published: 29 November 2021

Publisher's Note: MDPI stays neutral with regard to jurisdictional claims in published maps and institutional affiliations.

Copyright: (c) 2021 by the authors Licensee MDPI, Basel, Switzerland. This article is an open access article distributed under the terms and conditions of the Creative Commons Attribution (CC BY) license (https:// creativecommons.org/licenses/by/ $4.0 /)$.
1 School of Ecology and Environment Studies, Nalanda University, Rajgir 803116, Bihar, India; rakesh.kumar.PhD@nalandauniv.edu.in (R.K.); rama.sees19@nalandauniv.edu.in (R.S.); nishita.ivy.PhD@nalandauniv.edu.in (N.I.); pawantheone057@gmail.com (P.K.)

2 Aryabhatta Centre for Nanoscience \& Nanotechnology, Aryabhatta Knowledge University, Patna 800001, Bihar, India; pushpa.shalini@gmail.com (P.K.S.); rakeshsinghpu@gmail.com (R.K.S.)

3 Department of Chemistry, Sikkim Manipal Institute of Technology, Rangpo 737136, Sikkim, India

4 Department of Environmen tal Science and Engineering, Indian Institute of Technology, Indian School of Mines, Dhanbad 826004, Jharkhand, India; nishikant1490@gmail.com

5 Department of Biotechnology, School of Health and Allied Science, Arka Jain University, Jamshedpur 831001, Jharkhand, India

6 School of Biotechnology, Kalinga Institute of Industrial Technology, Bhubaneswar 751024, Odisha, India; 1960030@kiitbiotech.ac.in

7 Sustainable Intensification Innovation Lab, Department of Agronomy, Kansas State University, Manhattan, KS 66506, USA; pjha@ksu.edu (P.K.J.); vara@ksu.edu (P.V.V.P.)

8 Faculty of Environment, University of Waterloo, Waterloo, ON N2L 3G1, Canada

9 Institute of Environment and Sustainable Development, Banaras Hindu University, Varanasi 221005, Uttar Pradesh, India; rajeevprataps@gmail.com

10 Mahavir Cancer Sansthan and Research Centre, Phulwarisharif, Patna 801505, Bihar, India; ghosh51@hotmail.com

11 Bihar Pollution Control Board, Patna 800010, Bihar, India

* Correspondence: pk3gupta@uwaterloo.ca (P.K.G.); psharma@nalandauniv.edu.in (P.S.)

Abstract: Fluoride is widely found in soil-water systems due to anthropogenic and geogenic activities that affect millions worldwide. Fluoride ingestion results in chronic and acute toxicity, including skeletal and dental fluorosis, neurological damage, and bone softening in humans. Therefore, this review paper summarizes biological processes for fluoride remediation, i.e., bioaccumulation in plants and microbially assisted systems. Bioremediation approaches for fluoride removal have recently gained prominence in removing fluoride ions. Plants are vulnerable to fluoride accumulation in soil, and their growth and development can be negatively affected, even with low fluoride content in the soil. The microbial bioremediation processes involve bioaccumulation, biotransformation, and biosorption. Bacterial, fungal, and algal biomass are ecologically efficient bioremediators. Most bioremediation techniques are laboratory-scale based on contaminated solutions; however, treatment of fluoride-contaminated wastewater at an industrial scale is yet to be investigated. Therefore, this review recommends the practical applicability and sustainability of microbial bioremediation of fluoride in different environments.

Keywords: fluoride; microbes; remediation; bioremediation; mycoremediation; phytoremediation

\section{Introduction}

Fluorine is a highly electronegative halogen [1] and essential component (13th) in the Earth's crust with $625 \mathrm{mg} \mathrm{kg}^{-1}$ average concentration [2,3]. Fluoride exposure in the environment occurs through geogenic and anthropogenic sources. Fluorine-rich minerals 
such as apatite $\left(\mathrm{Ca}_{5}(\mathrm{Cl}, \mathrm{F}, \mathrm{OH})\left(\mathrm{PO}_{4}\right)_{3}\right)$, amphiboles $\left(\mathrm{A}_{0-1} \mathrm{~B}_{2} \mathrm{C}_{5} \mathrm{~T}_{8} \mathrm{O}_{22}(\mathrm{Cl}, \mathrm{F}, \mathrm{OH})\right)$, cryolite $\left(\mathrm{Na}_{3} \mathrm{AlF}_{6}\right)$, fluorite $\left(\mathrm{CaF}_{2}\right)$, micas $\left[\left(\mathrm{AB}_{2-3}[\mathrm{X}, \mathrm{Si}]_{4}\right)_{10}(\mathrm{O}, \mathrm{F}, \mathrm{OH})_{2}\right]$, sellaite $\left(\mathrm{MgF}_{2}\right)$, and topaz $\left(\mathrm{Al}_{2} \mathrm{SiO}_{4}\left(\mathrm{~F}, \mathrm{OH}_{2}\right)\right)$ are major geogenic sources of fluoride and can be found all over the world $[4,5]$. Fluoride in soil-water systems mainly occurs due to volcanic eruption, weathering, and leaching of rocks [6]. Thus, weathering and leaching of fluoride-bearing minerals are the primary sources of geogenic contamination and are typically associated with low calcium and high bicarbonate ions [4,7]. Churchill et al. [8] stated that coal also contains $295 \mathrm{mg} \mathrm{L}^{-1}$ of fluorine. Precipitation and air deposition are also geogenic sources of fluoride with concentrations in the range 0.00001 to $0.0004 \mathrm{mg} \mathrm{L}^{-1}$ or lower, as the fluoride analytical detection limit is $0.089 \mathrm{mg} \mathrm{L}^{-1}$ [9]. Anthropogenic activities are a potential source of fluoride ions in the soil-water systems. Anthropogenic sources include brick kilns, mining, pesticides and fertilizers, tiles, ceramics, and flux in steel and glass utilized in aluminum manufacturing [10-13]. In drinking water, the permissible limit established for fluoride by the World Health Organization (WHO) and Bureau of Indian Standards (BIS) is $1.5 \mathrm{mg} \mathrm{L}^{-1}$ [14-16]. According to the WHO report, more than 260 million individuals consume contaminated water of above $1 \mathrm{mg} \mathrm{L}^{-1}$ concentration [14]. Fluoride toxicity occurs around the world (Figure 1) in many countries, such as Sri Lanka, Pakistan, India, Turkey, Mexico, China, Iran, Italy, Algeria, United States, Korea, Kenya, Malawi, Ethiopia, Norway, Ghana, and Jordan $[6,9,10,12,13,17-24]$.

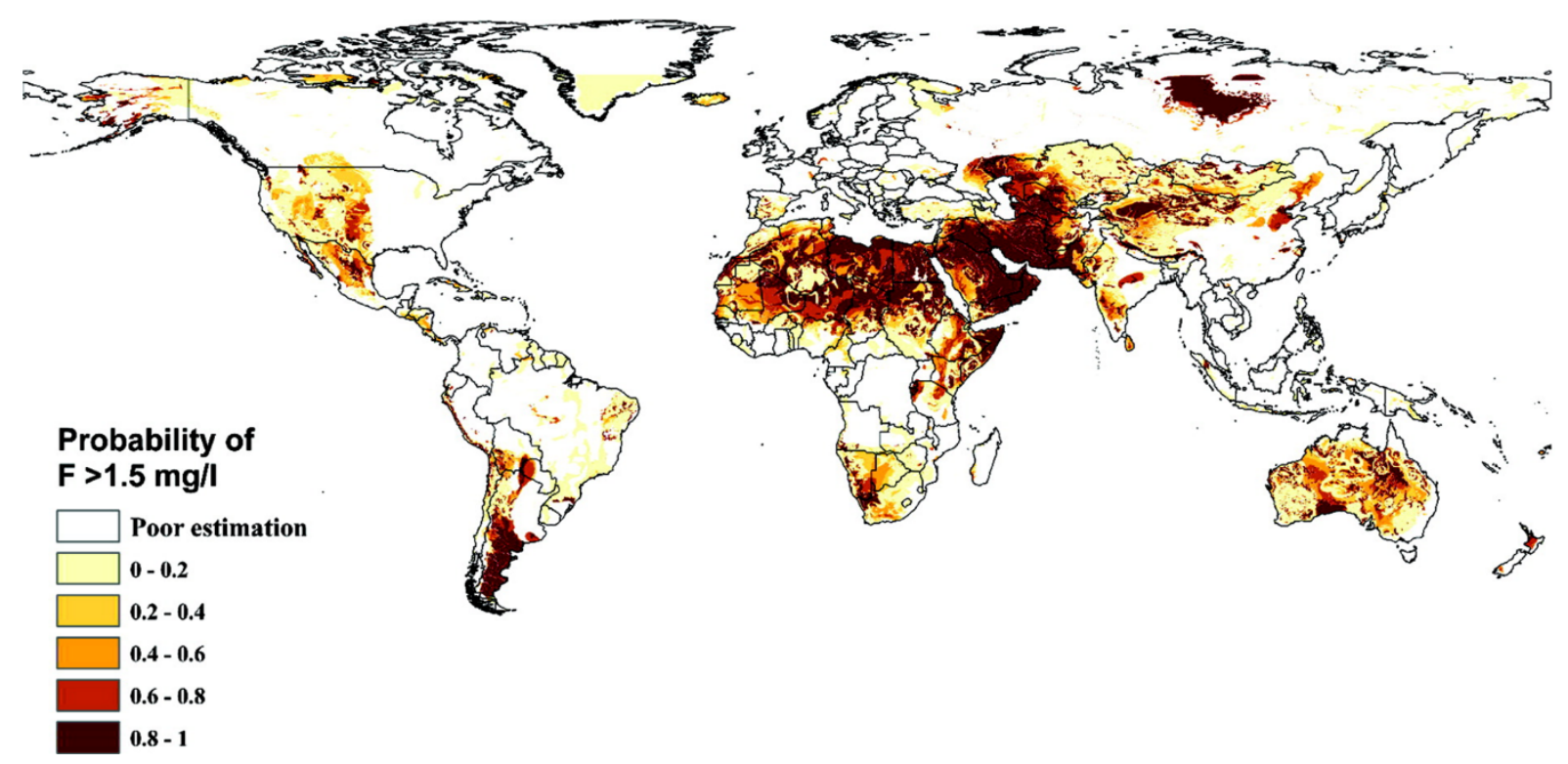

Figure 1. Predicted fluoride concentration in groundwater worldwide as per World Health Organization (WHO) permissible limit for drinking purposes. Adapted from Amini et al. [25].

Malago et al. [26], in a review, reported that African countries, such as Tanzania, Ethiopia, and Kenya, have groundwater and surface water contaminated with fluoride due to basaltic and volcanic rocks, in the range of $250-2800 \mathrm{mg} \mathrm{L}^{-1}$. In Kenya, fluoride concentration in the groundwater is up to $2800 \mathrm{mg} \mathrm{L}^{-1}$, geographically locked with volcanic rocks in the Rift Valley region [27]. Similarly, high fluoride concentration has been observed in Nigeria due to igneous and volcanic rocks [28]. In India, fluoride concentrations were reported in the range of $0.1-61.4 \mathrm{mg} \mathrm{L}^{-1}$ in groundwater (Table S1) $[9,17,29-80]$. Numerous factors influence the fluoride contamination levels in soil-water systems, including $\mathrm{pH}$, temperature, geological formations, residence time during interaction with soil and water, and the solubility of fluoride-rich minerals [81,82].

Fluoride needs to be removed from the contaminated soil-water systems considering its harmful effects on humans, animals, and plants. Defluoridation of water can be accomplished using different techniques, such as coagulation, ion exchange, chemical precipitation, membrane separation, electrodialysis, electrolysis, and adsorption [10,12,83-93]. 
Currently, ion exchange resins are considered efficient materials for removing anionic and cationic pollutants from water. Although ion exchange is a fast and adjustable stoichiometric method of fluoride removal, it is expensive, generates a considerable amount of residue, and has complexity in resins; moreover, its interfering ion affects the removal efficiency $[94,95]$. In the adsorption process, adsorbents used for the fluoride removal are activated alumina [87,96], activated carbon prepared from Moringa indica bark [97], laterite [98], and waste residue [99]. However, these methods have limitations such as high energy consumption, high cost, production of secondary contaminants, and inefficiency in removing pollutants from wastewater [100]. Microorganisms are an alternative approach for fluoride removal that has recently gained prominence in toxic element removal. Microorganisms can effectively remediate heavy metals and also reduce and oxidize transition metals. Microbes can efficiently remove fluoride because of their bacterial cell wall composition, including amines, carboxylates, and phosphate [101-103]. Many microorganisms have been used to eliminate fluoride ions from wastewater, such as bacterium Acinetobacter sp. (GU566361) [100], bacterium Providencia vermicola (KX926492) [104], cyanobacteria [105], and Aspergillus niger [106]. Another advantage of using microbes for fluoride removal is its simple operation method, cost-effectiveness, low energy requirement, and minimal generation of secondary pollutants [104].

This paper summarizes sources, toxicity, geochemistry, and bioaccumulation of fluoride in plants, including microbial technology available for fluoride remediation. The primary objectives of this review are to highlight the (a) source, toxicity, and geochemistry of fluoride ions in various environments; (b) solubility and bioavailability of fluoride in subsurface systems; (c) fluoride uptake and bioaccumulation in plants; and (d) microbial approaches for fluoride remediation. Several potential future perspectives are proposed for further studies using bioaccumulation and microbial remediation methods for fluoride removal.

\section{Sources and Geochemistry of Fluoride in Environmental Compartments}

Natural sources contribute to a massive percentage of fluoride in soil, water, and plant systems (e.g., forage, grasses, and grains), which affects the occurrence and severity of fluorosis. Fluoride-enriched minerals in the subsurface zone cause high concentrations in natural water resources through geogenic contamination, as fluoride ions are being released from weak structural zones into soils and groundwater [107]. Rocks enriched with fluoride minerals are extensive fluoride reservoirs, as groundwater runs via fractures or pores of rocks or consolidated materials, such as granitic rocks; therefore, the availability of fluorine in the Earth's crust supports emergence in groundwater [108]. Minerals containing fluoride, such as hornblende, biotite, and muscovite, have been discovered near volcanic rocks and could discharge fluoride into the groundwater [109].

In groundwater, fluoride contaminations are mainly from fluoride-bearing mineral rocks via dissolution, ion exchange, and sorbent surface desorption, including anthropogenic pollution. Four key processes that control hydrochemistry of groundwater resources are nitrate oxidation of organic carbon, silicate mineral weathering, soluble salt, and sulfate mineral dissolution in aquifers, in which fluoride enrichment is directly linked with weathering of silicate minerals [110]. The primary source of fluoride contamination in the groundwater is the dissolution of minerals such as fluorite and biotite in laterite sheeted basalt and granite gneiss. Consequently, the depth of the groundwater level also influences the fluoride contents [111]. For example, high fluoride concentrations in groundwater from deep aquifers and geothermal springs have been attributed to geothermal temperature as one of the driving mechanisms [112]. High fluoride concentrations have been reported in sub-Saharan Africa and East Africa due to volcanic activity. Volcanic ash is a natural source, has a high fluoride concentration, and is easily soluble in water [112].

Human activities (i.e., domestic waste, pesticide, and fertilizer use in agriculture) and industries pollute the environment with significant fluoride inputs to the subsurface aquatic system [113]. Agricultural fertilizers and coal burning are two major anthropogenic 
contributors to fluoride [114,115]. Phosphate fertilizers influence the fluoride level in irrigated lands [116]. At the same time, coal is being utilized for combustion in several industries and brick kilns. Inappropriate fly ash disposal on the surface of the ground leads to high fluoride concentration in the groundwater. The dispersion of particulate fluoride from the aerial emission reaches the surface and, after rains, percolates due to precipitation, reaching the groundwater zone $[117,118]$.

Compared to shallow aquifers, deep aquifers have bicarbonate $\mathrm{HCO}_{3}{ }^{-}$groundwater with high concentrations of fluoride. Fluoride leaching into groundwater could be caused by physicochemical circumstances, such as decomposition, dissociation, and subsequent dissolution, as well as long residence time [49]. Regional distribution of fluoride in the groundwater, as demonstrated by hydrogeochemical investigations, denoted high fluoride concentration in coal-bearing formation across Raigarh district, Chattisgarh, India [37]. Mineral composition of metamorphic rocks and granitoids is linked to the geogenic source of fluoride contamination in groundwater.

Marine aerosols, volcanic emissions, and anthropogenic inputs are the primary sources of fluoride in rainfall. Fluoride concentrations in the rain typically vary from 0.02 to $0.2 \mathrm{mg} \mathrm{L}^{-1}$, with pure and continental showers [119]. Rainwater appears to play a minor role in contributing to groundwater [91]. However, fluoride is absorbed from erosion and transmitted to seawater via streams or rivers, resulting in a relatively high fluoride concentration of 1.0-1.4 mg L $\mathrm{m}^{-1}$ in seawater. Fluoride levels are limited in groundwater with sufficient calcium due to saturation with the mineral fluorite. Hydrogeochemistry and mineral-water interaction, such as calcite and fluorite resulting from fluorapatite $\mathrm{Ca}_{5}\left(\mathrm{PO}_{4}\right)_{3} \mathrm{~F}$ dissolution are contributing to fluoride enrichment in the groundwater [120]. Ahmed [121] suggested regularly monitoring fluoride concentration in groundwater, particularly in deserts and reclaimed areas where the soil surface has minimal clay contents and direct mixing of fluoride-contaminated water for irrigation. Fluorite dissolution and anion exchange with micaceous minerals and their clay products are sources of groundwater fluoride [82]. Overexploitation of groundwater exacerbates drinking water supply shortages and hastens fluoride movement into groundwater [122]. The average fluoride content in rocks and soils has been found in the following order: marl > alluvial sediments $>$ limestone, indicating marl is a potential source of fluoride, as marl interbedded with limestone has maximum fluoride [123,124]. Fluoride in soils is primarily found in residual and water-soluble fractions, and it had little to do with the available binding sites. As a result, fluoride in soils is mobile, making it easily leachable into groundwater [125]. The fluoride presence is relatively high in falling groundwater tables because of possible direct evaporation of groundwater from wells. Water level rises owing to dilution by fresh rainwater recharge; i.e., fluoride content is low but the deep borewells contain excessive fluoride [126].

\section{Toxicity of Fluoride to Human and Animal Health}

The influence of fluoride on mineralized tissues prevents tooth decay and enables enamel to be more resistant to acid attacks $[18,127]$. However, excessive fluoride intake causes human health risks, including chronic and acute toxicity [128]. Acute toxicity includes diarrhea, abdominal pain, vomiting, dehydration, and excessive salivation, which occur rapidly if intake exceeds the limit. Fluoride ingestion of $35-70 \mathrm{mg} \mathrm{kg}^{-1}$ of body weight orally can cause rapid adverse effects [129]. Long-term fluoride ingestion, even in small amounts of fluoride, can cause chronic toxicity. Prolonged fluoride consumption above $8 \mathrm{mg} \mathrm{L}^{-1}$ causes skeletal fluorosis [130], arthritis, cancer, osteoporosis, infertility, thyroid disorder, Alzheimer's disease, and brain damage [1,12,131-133]. The high availability of fluoride in bones makes them brittle and eventually develops into a severe health issue called skeletal fluorosis [128]. Fluoride is converted into hydrogen fluoride in acidic environments such as the stomach. The neutrally charged hydrogen fluoride molecule easily passes through the cell membrane to improve intracellular intake [134]. Fluoride toxicity causes oxidative stress, i.e., production of ROS (reactive oxygen species) and RON 
(reactive nitrogen species), and interrupts natural antioxidant defense mechanisms [135]. Islam and Patel [136] reported that excess fluoride ingestion could affect proteins, lipids, carbohydrates, and vitamins. It also affects various organs, including kidney, heart, liver, lungs, and gastrointestinal tract [137]. People suffering from kidney issues have a higher risk of fluoride accumulation, leading to death [138]. Studies have reported that excessive fluoride use also affects the brain. Excess of fluoride impacts the peripheral nervous system function and structure and also causes a reduction in aerobic metabolism $[139,140]$. Excessive fluoride affects the kidney, including the urinary tract, and there may also be color change to red and itching near the axilla [141]. Fluoride can cause brittle bones and increase density and bone mass [141]. A report obtained from animal experiments shows that fluoride ingestion can affect the brain and antioxidant defense system [142]. The toxicity of fluoride to cattle has been reported to include a thyrotoxic effect on chronic fluorosis and disruption of the secretion of thyroxin hormones in mammalian cells [143-145]. Excessive fluoride affects more aquatic animals living in soft water than those living in hard water. This is due to the bioavailability of fluoride decreasing with an increase in water hardness; it can affect the growth of the organisms [141].

\section{Factors Affecting Mobility and Bioavailability of Fluoride in Subsurface and Surface Systems}

\subsection{Groundwater}

Major sources for fluoride contamination in groundwater include fluoride-bearing minerals in the host rocks and their interaction with groundwater through chemical processes such as breakdown, dissolution, and dissociation. Evaporation, chemical weathering, and ion exchange are the key geochemical regulating factors of fluoride enrichment in groundwater [146]. Fluoride enrichment in groundwater is most commonly caused by the dissolving of the fluoride-rich minerals such as amphiboles and micas found in aquifers, which are primarily granitic-rich rocks. Longer residence time results in substantial waterrock interactions for fluoride mineral resolution [147]. In shallow groundwater, soluble salts are gradually reduced, $\mathrm{pH}$ is increased, and the dissolution fluorite equilibrium is observed in areas with high fluoride concentration [148]. The predominant hydrogeochemical mechanisms in groundwater are silicate weathering and ion exchange. Therefore, weathering and cation exchange influence the major groundwater chemistry, significantly affecting fluoride enrichment; an essential natural activity is controlling groundwater chemistry [149]. Groundwater alkalinity seems to play an essential role in the dissolution of fluoride ions from their parent minerals. A high alkaline solution is frequently coupled with high fluoride content. Hence, chemical weathering with high alkalinity supports a high fluoride content in groundwater [66]. Weathering and mineral dissolution of fluoride are assisted via cation exchange of $\mathrm{Na}^{+}$and $\mathrm{K}^{+}$ions in the aquifer substrate against $\mathrm{Ca}^{2+}$ and $\mathrm{Mg}^{2+}$ ions. Alkaline $\mathrm{pH}$, high $\mathrm{HCO}_{3}^{-}$concentrations, and a high $\mathrm{Na} / \mathrm{Ca}$ ratio are the best conditions for raising fluoride levels in groundwater [150].

Groundwater enriched with sodium lacks calcium and favors fluoride exudation from geological formations. Therefore, precipitation of $\mathrm{CaCO}_{3}$ creates routes for the dissolution of $\mathrm{CaF}_{2}$, which has enhanced fluoride ions in groundwater [151]. For a long time, the mixture of granitic, $\mathrm{NaF}$, and $\mathrm{CaF}_{2}$ rocks impact fluoride in the groundwater [152]. Increases in fluoride concentration had been observed in deep groundwater when groundwater levels increased, leading to the leaching of fluoride-rich salts from the unsaturated zone [153]. Groundwater quality is lower in the dry season than in the wet season due to the lithologic effect [154]. This suggests that rainwater induces dilution, recharging the aquifer and lowering the fluoride level [155]. There is a significant relation between fluoride concentration and $\mathrm{pH}$, as well as a positive correlation between fluoride and $\mathrm{HCO}_{3}^{-}$ions. As a result, an alkaline $\mathrm{pH}$ promotes fluoride dissolution, and total dissolved solids (TDS) is positively correlated with fluoride ions [156] but has a negligible association with $\mathrm{Ca}^{2+}$. Fluorite dissolution is favored by a lack of calcium ion concentration in the groundwater due to calcite precipitation, resulting in excess fluoride concentration [50]. Fluoride concentration has a positive relationship with $\mathrm{pH}$ and $\mathrm{HCO}_{3}^{-}$, whereas $\mathrm{Cl}, \mathrm{Ca}, \mathrm{Mg}$, and $\mathrm{Na}$ initially 
increase and then decrease as the fluoride in water increases [157]. Furthermore, alkaline nature significantly influences the fluoride concentration, i.e., high hydrocarbons, $\mathrm{Na}^{+}$, and $\mathrm{HCO}_{3}^{-}$water types [158]. Fluoride level in water is closely related to two primary types of groundwater enriched with $\mathrm{Ca}-\mathrm{Mg}-\mathrm{HCO}_{3}$ and $\mathrm{Na}-\mathrm{HCO}_{3}$. Fluoride levels could be highest in $\mathrm{Na}-\mathrm{HCO}_{3}$ and lowest in $\mathrm{Ca}-\mathrm{Mg}-\mathrm{HCO}_{3}$ geological rocks. The relative abundance of groundwater ions is $\mathrm{Na}^{+}>\mathrm{Ca}^{2+}>\mathrm{Mg}^{2+}>\mathrm{K}^{+}$for cations and $\mathrm{HCO}_{3}^{-}>\mathrm{Cl}^{-}$ $>\mathrm{SO}_{4}^{2-}>\mathrm{NO}_{3}^{-}>\mathrm{F}^{-}$for anions, according to statistical analysis [159]. The geochemical behavior of fluoride in groundwater is likewise linked to releasing $\mathrm{Na}$ and eliminating $\mathrm{Ca}^{2+}$ ions due to ionic exchange. Lowering $\mathrm{Ca}^{2+} / \mathrm{F}^{-}$activity in groundwater through ion complexation, cation exchange, and ionic strength of salts is crucial to control the groundwater fluoride concentration [17]. The equilibrium of fluorite controls the fluoride concentration, according to the thermodynamic link between the activities of $\mathrm{Ca}^{2+}$ and $\mathrm{F}^{-}$ ions [20]. In spite of the high fluorine content of the riebeckite granites, the contribution of fluoride is concentrated due to groundwater flow [160]. With seawater and brine water, fluorine release from the rock accelerates due to high salinity. Since the seawater intrusion is suggested by high $\mathrm{EC}, \mathrm{Na}^{+}$, and $\mathrm{Cl}^{-}$concentrations in the coastal region, the upper region exhibits an increase in these ions during the pre-monsoon season. This is owing to the high mineralization caused by the evaporation and weathering of silicates [161]. As a result, seawater intrusion could significantly increase fluorine leachability and be a key factor in fluorine enrichment [162].

The presence of coexisting ions has been a key component in assessing the dissolution processes of fluoride-rich minerals [163]. The causes of the varying fluoride concentration levels reported in groundwater are the simultaneous occurrence of fluorite dissolution in different concentrations, unique periods of interaction, leaching of fluoride from several other silicate minerals, and saturation regarding carbonate minerals [164]. The aquifers, on the other hand, are dominated by carbonate weathering and reverse ion exchange mechanisms [165]. The majority of them are unknown depending on water evaporation, and boiling water enhances the fluoride concentration. Due to a lack of knowledge, people continue to boil water longer than necessary to eliminate microbes [166-168].

High-fluoride-content groundwater is found in the intercalated micaceous sand aquifer and clay strata. Clay layer sorption-desorption dynamics, as well as shifting $\mathrm{Na}^{+} / \mathrm{Ca}^{2+}$ and $\mathrm{pH}$ ratios, may result in a greater fluoride content in groundwater [80]. Many factors influence fluorine adsorption and desorption by clay minerals; however, the main parameters influencing fluorine enrichment and leaching in the soil can be determined by considering interactions [169]. In the temporal dimension, fluoride concentrations fluctuated little, but in the geographical dimension, they varied a lot. The elevated fluoride concentrations were not produced by the filter depth or the water table, the groundwater column or regolith thicknesses, or the soil type distribution at the sampling sites [170].

\subsection{Soil}

Fluoride in soil was found to be a mobile element. Furthermore, relative mobility suggested that soils played a more significant role in releasing fluoride into groundwater than rocks. Fluoride solubility in the soil is profoundly affected by soil $\mathrm{pH}$, texture, organic matter, and concentration of other ions [171-175]. In soil, fluoride concentrations vary from 100 to $400 \mathrm{mg} \mathrm{L}^{-1}$ [13]; fluoride in soil is primarily combined with clay fraction of the soil colloids, and its mobility depends on the type of sorbents, $\mathrm{pH}$, soil salinity, and sorption capacity $[5,13,176]$. For example, acidic soils can increase the bioavailability of fluoride; however, solubility decreases at $\mathrm{pH}$ in the range of $6-6.5$ [171,172,177]. Fluoride generally combines with aluminum or calcium in the soil, so clay soil or silts have a higher fluoride concentration than sandy soil [178]. Fluoride mobility is affected at the high salinity; i.e., other ions in high concentration compete with fluoride for sorption sites [13]. Moreover, evapotranspiration can also regulate soil fluoride concentration and salinity [179]. Fluoride is mainly immobile in soil because it is not readily soluble and exchangeable, but soluble fluoride is vital to plant and animal growth $[180,181]$. 
Soil chemistry significantly affects fluoride speciation, solubility, and bioavailability. The physicochemical properties of the soil influence the fluoride ion bioavailability [182]. The formation of iron, aluminum, and hydrogen complexes in natural soil also decreases the solubility of fluoride ions $[172,177,183]$. Moirana et al. [184] observed that fluoride fraction is maximum in the water-soluble form; therefore, the bioavailability of fluoride in the soil is denoted as total fluoride, the sum of water-soluble fluoride ions, exchangeable free fluoride ions, iron/aluminum-bound fluoride ions, organic-matter-bound fluoride ions, and residual fluoride ions. Loganathan et al. [177] reported that fluoride accumulation is significantly correlated with organic matter and aluminum oxide contents, as fluoride ions bind with aluminum oxides adsorbed onto organic matter present in the soil. Therefore, desorption of fluoride from the soil surfaces has been observed due to lower solubility under neutral to alkaline soil conditions [185]. Increased $\mathrm{OH}^{-}$ion concentrations displace the adsorbed fluoride ions onto colloid surfaces as pH increases [186]. Guo et al. [187] have observed that $-\mathrm{OH}$ ions replace the exchangeable fluoride ions in an alkaline environment. Jeong et al. [188] analyzed the fluoride stability in soil using calcium hydroxides and reported that the bioavailability of fluoride was reduced after calcium hydroxide treatment. The solubility of fluoride ions significantly depends upon soil $\mathrm{pH}(<4.9)$ and increases the organic matter [177], which possibly contaminates the groundwater for coarse-textured soil packing and shallow aquifers. Gan et al. [189] observed that fluoride ions become immobilized after an application of nano-hydroxyapatite in acidic fluoride-contaminated soil due to insoluble $\mathrm{CaF}_{2}$ formation and replacement of fluoride with $\mathrm{OH}^{-}$ions. Considering the soil textures, the bioavailability of fluoride ions is significant in sandy soils, whereas desorption occurs mainly in clay textured soils because of the large surface area per unit weight $[177,187]$.

\section{Fluoride Uptake and Bioaccumulation in Plants and Foods}

Fluoride is a common phytotoxic contaminant for plants [190]. Plant species absorb fluoride from water and soil via roots and air through leaves [190,191], accumulate fluoride in different parts of the plant, and acquire fluoride at a higher level than in the environment $[192,193]$. Fluoride accumulation in plants depends on various factors such as fluoride concentration in soil, plant species, and soil properties [178]. Fluoride accumulation in soil surrounds roots and disturbs the biochemical, morphological, and physiological behavior of plants. Plants grown in uncontaminated soils have an average fluoride concentration of less than $10 \mathrm{mg} \mathrm{kg}^{-1}$ [194]. Besides this, fluoride toxicity in plants depends on the level, frequency, and duration of exposure and the genotype of plants $[1,195]$. The presence of other anions and changes in $\mathrm{pH}$ also influences the fluoride accumulation in soil [131]. The growth and productivity of crop species and other plants are also affected detrimentally because of fluoride exposure, even at lower concentrations [196]. The minimal optimal limit for fluoride accumulation in plants is $10 \mathrm{mg} \mathrm{L}^{-1}$; however, fluoride uptake levels in Trifolium repens and Lolium multiflorium were $30 \mathrm{mg} \mathrm{kg}^{-1}$ and $50 \mathrm{mg} \mathrm{kg}^{-1}$ [197]. Therefore, it has been reported that fluoride toxicity can adversely impact seed germination, cellular enzymatic activity, crop yield, etc., as shown in Table 1 [191,198-202]. 
Table 1. Impacts of fluoride uptake and accumulation on plants and their physiological behavior.

\begin{tabular}{|c|c|c|c|c|}
\hline Plants & $\begin{array}{c}\text { Fluoride } \\
\text { Concentration }\end{array}$ & Highlights and Key Points & Growth and Development & References \\
\hline \multirow[t]{2}{*}{$\begin{array}{l}\text { Paddy rice } \\
\text { (Oryza sativa) }\end{array}$} & & $\begin{array}{c}75 \mathrm{mg} \mathrm{kg}^{-1} \text { fluoride accumulated in } \\
\text { dry biomass }\end{array}$ & \multirow{2}{*}{$\begin{array}{l}\text { Seed germination reduced to } \\
96 \% \text { and } 92 \% \text { for } 20 \text { and } \\
30 \mathrm{mg} \mathrm{L}^{-1} \text { of fluoride }\end{array}$} & \multirow[t]{2}{*}{ [199] } \\
\hline & $30 \mathrm{mg} \mathrm{L}^{-1}$ & $\begin{array}{c}2000 \mathrm{mg} \mathrm{kg}^{-1} \text { fluoride accumulated } \\
\text { in dry biomass }\end{array}$ & & \\
\hline $\begin{array}{l}\text { Seedlings of } \\
\text { paddy rice }\end{array}$ & 25 and $50 \mathrm{mg} \mathrm{L}^{-1}$ & $\begin{array}{l}\text { Decrease in seedling biomass and } \\
\text { shoot and root length }\end{array}$ & $\begin{array}{l}\text { Seed germination reduced to } \\
26.14 \% \text { and } 47.47 \% \text { for } 25 \\
\text { and } 50 \mathrm{mg} \mathrm{L}^{-1} \text { of fluoride }\end{array}$ & [203] \\
\hline Cajanus cajan L. & $75 \mathrm{mg} \mathrm{L}^{-1}$ & $\begin{array}{l}\text { Decrease in seed growth }(25 \%) \text {, root } \\
\text { length }(53 \%) \text {, and dry biomass }(68 \%) \\
\text { Decrease in seed germination (from }\end{array}$ & $\begin{array}{l}\text { Induces active } \\
\text { oxygen species }\end{array}$ & [202] \\
\hline $\begin{array}{l}\text { Tomato (Solanum } \\
\text { Lycopersicum) plants }\end{array}$ & $0-100 \mathrm{mg} \mathrm{L}^{-1}$ & $\begin{array}{l}\text { Decrease in seed germination (trom } \\
7.1 \text { to } 1.1 \mathrm{mg}^{-1} \text { day }{ }^{-1} \text { ), leaf area (from } 2 \\
\text { to } 8 \mathrm{~m}^{2} \text { ), plant growth rate, and NAR } \\
\text { (from } 52 \text { to } 22 \mu \mathrm{dav}^{-1} \text { ) }\end{array}$ & $\begin{array}{l}\text { Induces metabolic changes } \\
\text { and decrease in } \\
\text { germination rate }\end{array}$ & [204] \\
\hline $\begin{array}{l}\text { Paddy rice } \\
(\text { Oryza sativa })\end{array}$ & $25 \mathrm{mg} \mathrm{L}^{-1}$ & $\begin{array}{c}\text { High fluoride accumulation in shoot } \\
\text { and root; high concentrations of } \\
\text { chlorophyll, methylglyoxal, } \\
\text { malondialdehyde, lipoxygenase } \\
\text { activity, etc. }\end{array}$ & $\begin{array}{l}\text { Inhibits shoot and } \\
\text { root length }\end{array}$ & [205] \\
\hline $\begin{array}{l}\text { Aromatic and } \\
\text { nonaromatic } \\
\text { indica rice }\end{array}$ & 15 and $25 \mathrm{mg} \mathrm{L}^{-1}$ & $\begin{array}{l}\text { Decrease in dry biomass (91 mg) and } \\
\text { vigor index (1229) as compared to } \\
\text { controlled (122.5 mg and 1920, } \\
\text { respectively); increase in fluoride } \\
\text { accumulation }\left(39.5 \mathrm{mg} \mathrm{g}^{-1}\right), \\
\text { methyl-glyoxal }\left(152.8 \mathrm{mg} \mathrm{g}^{-1}\right), \\
\text { protein carbonylation }\left(1903 \mathrm{mg} \mathrm{g}^{-1}\right), \\
\text { etc. as compared to controlled (0.7, } \\
\text { 121, and } 301.2 \mathrm{mg} \mathrm{g}^{-1}, \text { respectively) } \\
\text { for } 25 \mathrm{mg} \mathrm{L}^{-1}\end{array}$ & $\begin{array}{l}\text { Shoot tip burning and } \\
\text { chlorosis, reduction in } \\
\text { abscisic acid, and inhibition } \\
\text { of polyamine biosynthesis } \\
\text { and the } \\
\text { ascorbate-glutathione cycle }\end{array}$ & [206] \\
\hline Rice (Oryza sativa) & $25 \mathrm{mg} \mathrm{L}^{-1}$ & $\begin{array}{l}\text { Decrease in germination }(21 \%), \\
\text { seedling biomass }(28 \%) \text {, root length } \\
(33.8 \%) \text {, and shoot length }(17.2 \%)\end{array}$ & $\begin{array}{l}\text { Oxidative stress, reduction in } \\
\text { chlorophyll content }\end{array}$ & [207] \\
\hline
\end{tabular}

Figure 2 shows how plants uptake fluoride from contaminated soil and air, translocate it and accumulate it in cell walls. Plants are vulnerable to fluoride accumulation, and their growth and development process can be affected negatively even with a lower level of fluoride deposition [196]. However, plants such as Zea mays and Lupinus luteus were found fluoride-tolerant because of their ability of protein synthesis and self-protection against protein degradation [208].

Although some plant species have an inherent ability to tolerate fluoride, the growth and metabolism of numerous crop species are inhibited by excessive fluoride [191]. Biochemical, physiological, and molecular alterations could occur in plants because of prolonged contact with fluoride [209]. However, the effect of fluoride on plant species could be acute, chronic, or severe. Metabolic activity, nutrient uptake, germination, growth and yield, leaf and fruit damage, photosynthesis, respiration, protein synthesis, accumulation of nucleotide synthesized biomass, carbohydrate metabolism, enzyme activities, patterns of gene expression, and ROS production could be negatively impacted in plants because of fluoride toxicity $[196,209,210]$. It has been observed by Mondal [211] that the pattern of germination decreases gradually with the increase in fluoride pigment concentration in rice (Orzya sativa L.). A decrease in germination, root growth, and inhibition of catalase activities was also observed in three cultivars of winter wheat (Triticum aestivum L.) [212]. Fluoride accumulation in crops can also vary based on varieties of the same species. It was found that an increase in fluoride concentrations impacted the fresh weight, dry weight, vigor index, and relative water content of aromatic rice variety Gobindobhog (GB) to a lesser level compared to a nonaromatic rice variety, IR-64 [206]. Plants absorb fluoride from the air or soil through stomata or the root system. Fluoride ions enter directly into the 
xylem and phloem via the epidermis and cortex of secondary roots (Figure 2). After that,

fluoride diffuses from the plants through stomata [1].

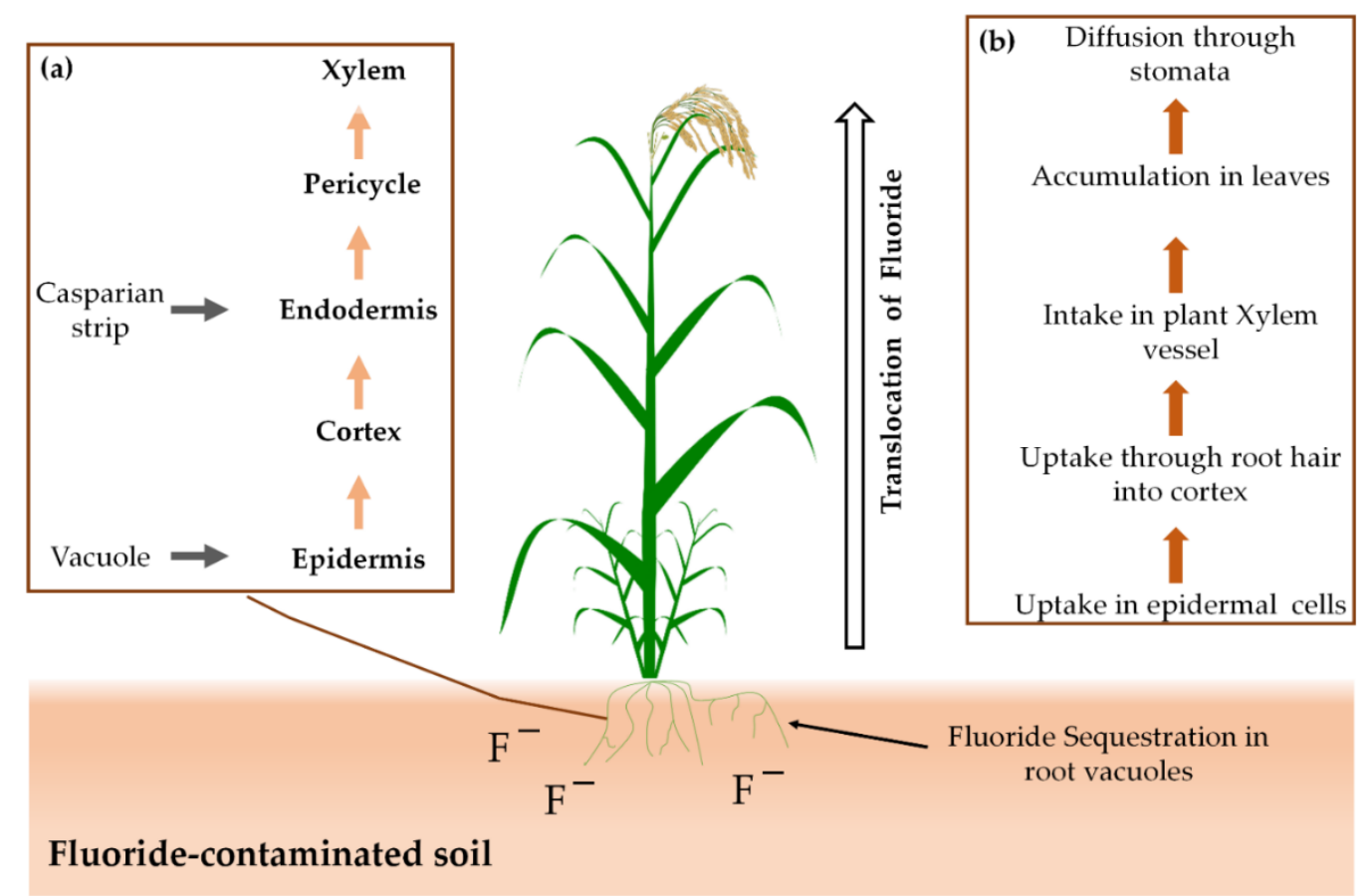

Figure 2. Fluoride uptake and accumulation in plants: (a) uptake mechanism in roots and (b) overall translocation from roots to shoots.

Gupta et al. [199] reported that physiological parameters, such as root and shoot length and total biomass, of paddy rice (Oryza sativa) decreased monotonically with an increase in fluoride concentration. Besides, seed germination is also reduced with high fluoride concentration $\left(>10 \mathrm{mg} \mathrm{L}^{-1}\right)$ and increases fluoride bioaccumulation in paddy rice (e.g., $75 \mathrm{mg}$ of fluoride accumulated per $\mathrm{kg}$ of dry biomass for $10 \mathrm{mg} \mathrm{L}^{-1}$ of initial fluoride concentration). Singh and Roychoudhury [203] exposed seedlings to two fluoride concentrations 25 and $50 \mathrm{mg} \mathrm{L}^{-1}$, which caused detrimental oxidative stress, such as decreases in seed germination, biomass, root and shoot length, and chlorophyll content, on seedlings of rice. Seedling biomass, root, and shoot length were decreased by $31.51 \%$ and $40.89 \%, 20 \%$ and $36 \%$, and $26 \%$ and $40 \%$ at fluoride concentrations of 25 and $50 \mathrm{mg} \mathrm{L}^{-1}$, respectively, to control (untreated) rice seedlings. Besides, chlorophyll contents were also reduced to 1.8 and 2.3 times for 25 and $50 \mathrm{mg} \mathrm{L}^{-1}$, respectively. Besides, Yadu et al. [202] reported that fluoride toxicity inhibits genomic template stability, protein content, fluoride accumulation in dry biomass, and membrane stability. However, toxicity enhances active oxygen species, cell death, lipase activity, DNA polymorphism, and protein carbonylation.

Baunthiyal and Ranghar [213] estimated the fluoride accumulation capacity of plants after a series of experiments. Plants tend to accumulate fluoride mainly in their root system [214]. Fluoride accumulation at higher levels has been found in roots compared to shoots for four different rice varieties [211]. Zouari et al. [215] also observed that fluoride content was higher in roots than leaves for olive (Olea europaea) plants. Loquat trees (Eriobotrya Japonica) exhibited adverse responses to fluoride air pollution as harmful effects on foliar water status, photosynthetic parameters, photosynthetic pigments, and cell membranes [216]. Fluoride toxicity leads to oxidative stress; a decrease in chlorophyll content; and changes in the concentrations of soluble sugars, nitrogen, proline, betaine, and macro- and micronutrients in plants [214]. Olive plants showed maximum reduction in antioxidant enzymes and mineral contents and an increase in oxidative stress at $80 \mathrm{mM}$ sodium fluoride (NaF) concentrations [215]. The yield of crops and vegetables can also be 
affected negatively by fluoride. The yield of eggplant or brinjal (Solanum melongena L.) was severely affected by sodium fluoride-related stress in a dose-dependent experiment. The maximum yield reduction was observed at $600 \mathrm{mg} \mathrm{L}^{-1} \mathrm{NaF}$ [217]. There are two pathways of the entrance of fluoride in plants: apoplastic transport system and anion channel [1]. From the study of Zhang et al. [190], it was observed that anion blockers inhibited the uptake of $\mathrm{F}^{-}$ions in tea plants (Camellia sinensis), and it was suggested that anion channels might play an essential role in the absorption of $\mathrm{F}^{-}$ions for the tea plants. Tea plants tolerate higher fluoride levels than other plants [218]. It was found that most of the $\mathrm{F}^{-}$ ions uptaken by the roots of tea plants were readily transported to the leaves through the xylem [190].

Fish and shellfish have fluoride content in solid foods, reflecting the fluoride found in ocean water. Significant fluoride levels have also been found in cereals, baked foods, bread, and other grain products $[219,220]$. Most vegetables have a minimal fluoride level, whether leafy, root, legumes, green, or yellow. In most experiments, the fluoride levels in fruits were lower than in vegetables [220]. Beverages are also a substantial source of fluoride exposure in the human diet, especially before widespread fluoridation of drinking water sources and the rise in bottled water consumption. Although tea contains fluorides, the amount varies depending on the type of tea, where it comes from, and leaf age [221].

Different techniques were examined to ameliorate fluoride toxicity in plants [196]. It has been observed that exogenous use of melatonin reduced the fluoride-mediated damages of rice seedlings by limiting fluoride uptake, stimulating the defense mechanism, and changing the homeostasis of phytohormones [222]. The use of calcium compounds such as $\mathrm{Ca}(\mathrm{OH})_{2}, \mathrm{Ca}\left(\mathrm{NO}_{3}\right)_{2}$, and $\mathrm{CaCl}_{2}$ as seed priming agents were also found effective in the amelioration of fluoride toxicity. It was found effective in improving growth performance by enhancing seed germination, the biomass of seedlings, the length of roots and shoots; preventing chlorophyll degeneration and electrolyte leakage; and reducing malondialdehyde levels, endogenous fluoride, and $\mathrm{H}_{2} \mathrm{O}_{2}$ [223]. Supplementation of sodium nitroprusside (SNP) was also found effective in rescuing catalase enzyme (CAT) activity, reducing fluoride uptake and membrane damage, and alleviating oxidative stress for Vigna radiata and Vigna mungo, along with increased growth recovery and upkeep of chlorophyll [224]. The addition of biochar ( $50 \mathrm{~g} \mathrm{~kg}^{-1}$ of soil) has also been found as the best treatment for lessening the fluoride toxicity in safflower plants [225]. Identification of fluoride-tolerant varieties of crop species and their incorporation into the breeding program can also be helpful to obtain desirable growth and yield of crops in fluoride-contaminated areas [196].

\section{Microbial Remediation Techniques for Fluoride Removal}

Microbial techniques are based upon using native or genetically modified microorganisms to remove fluoride ions from contaminated areas for environmental protection [103]. Different types of bacteria and other microorganisms rarely exhibited any toxic effect while exposed to high fluoride concentrations [213]. The antimicrobial effect of fluoride occurs by direct inhibition of enzymes by fluoride ion or hydrogen fluoride through the formation of phosphate analogs, such as alumino-fluoride or beryllium fluoride, that affect phosphate group transferring enzymes by inhibiting the adenosine triphosphate (ATP) synthesis. Microorganisms can perform various processes, such as mineralization, metal uptake, accumulation, sorption, enzymatic oxidation and reduction, extracellular precipitation, and efflux of xenobiotics using ionospheres to overcome fluoride toxicity [102,226]. Table 2 summarizes different bacterial genera that tolerate high concentrations of fluoride and their subsequent remediation. 
Table 2. Fluoride removal using microbial-based components.

\begin{tabular}{|c|c|c|c|}
\hline Microbes & $\begin{array}{c}\text { Fluoride } \\
\text { Removal (\%) }\end{array}$ & $\begin{array}{l}\text { Initial Fluoride Conc. } \\
\left(\mathrm{mg} \mathrm{L}^{-1}\right)\end{array}$ & References \\
\hline \multicolumn{4}{|l|}{ Bacterial Strain } \\
\hline Bacillus cereus & 21.91 & 10 & [227] \\
\hline Providencia vermicola (KX926492) & 82 & 20 & [104] \\
\hline Acinetobacter sp. RH5 & 25.1 & 10 & [228] \\
\hline Dead cells of Staphylococcus lentus (KX941098) & 85.03 & 10 & [229] \\
\hline Immobilized cells of Staphylococcus lentus (KX941098) & 92 & 20 & [229] \\
\hline Shewanella putrefaciens MTCC 8104 & 93.7 & 5 & {$[230]$} \\
\hline Pseudomonas aeruginosa & 22.7 & 10 & [102] \\
\hline NM25 (Bacillus flexus) & 67.45 & & [231] \\
\hline Acinetobacter sp. H12 & 81.91 & 3 & [232] \\
\hline $\begin{array}{c}\text { Acinetobacter sp. GU566361 } \\
\text { Cyanobacterial Strain }\end{array}$ & \multicolumn{2}{|c|}{ Cyanobacterial Strain } & [100] \\
\hline $\mathrm{Ca}^{2+}$-treated Anabaena fertilissima & 30 & 10 & [233] \\
\hline $\mathrm{Ca}^{2+}$-treated Chlorococcum humicola & 30 & 15 & [233] \\
\hline Spirogyra sp. IO1 & 64 & 5 & [234] \\
\hline Spirogyra sp. IO2 & 62 & 5 & [235] \\
\hline Nostoc sp. (BTA 394) & 73.43 & 10 & [236] \\
\hline $\mathrm{Ca}^{2+}$-treated live Nostoc sp. (394) & 86 & 10 & [236] \\
\hline Ulva fasciata & 90 & 5 & [226] \\
\hline Phormidium sp. & 60 & 3 & [237] \\
\hline Padina sp. & 85.95 & 2000 & {$[238]$} \\
\hline Starria zimbabweensis & 66.6 & 10 & {$[105]$} \\
\hline \multicolumn{4}{|l|}{ Fungal Strain } \\
\hline Pleurotus ostreatus 1804 & 52 & 5 & [239] \\
\hline Aspergillus penicilloides & 0.0014 & 50 & {$[240]$} \\
\hline Mucor racemosus & 0.0006 & 50 & [240] \\
\hline Pleurotus eryngii ATCC 90888 & 92 & 5 & [241] \\
\hline Aspergillus niger FS18 & 89 & 2 & [106] \\
\hline
\end{tabular}

\subsection{Bacterial Remediation}

Bacterial resistance to fluoride can be transient via horizontal gene transfer of plasmid genes between two cells or stable due to chromosomal mutations [242]. For example, cyanotoxins are intracellular toxins produced by cyanobacteria. The most common cyanotoxin produced by freshwater cyanobacteria is microcystin LR [105]. Fluoride is the most electronegative element, with proton as hydrogen fluoride, which enters the bacterial cells via diffusion, as hydrogen fluoride dissociates into $\mathrm{H}^{+}$and $\mathrm{F}^{-}$ions [243]. These ions interfere with the enzymes of glycolysis and fluoride-ATPases. In fluoride-resistant bacteria, these enzymes are believed to be mutated [244]. The bacterial cell wall comprises carbohydrates, phosphates, sulfhydryl, and amines; these groups efficiently reduce fluoride and thus help to adhere fluoride ions to the surface [104,243]. Different microbial processes can influence the toxicity and transport of metal into bacterial cells, including bioaccumulation, biosorption, biotransformation, and secretion of ligands such as siderophores or biosurfactants that affect solubility and thus the availability of these contaminants [103]. Mukherjee et al. [104] isolated the fluoride-resistant bacteria Providencia vermicola KX926492 from the water of severely affected rural areas and revealed that a maximum of $82 \%$ fluoride remediation was found. These bacteria can tolerate and survive high fluoride concentrations, thus providing a novel way of reducing fluoride toxicity. Many studies have reported the potential for bacterial remediation of heavy metals, such as chromium $[245,246]$, cadmium and lead [247,248], copper, and aluminum cobalt [249]. Chouhan et al. have isolated bacteria from well water and soil, and a maximum of $22.7 \%$ fluoride removal was achieved by Pseudomonas aeruginosa. These bacteria express extra protein bands on SDS-PAGE assay compared to bacteria growing in the absence of fluoride. These protein bands may be of the ionosphere, which has a high affinity for anion binding [102]. Few studies have isolated halophilic Bacillus sp., which tolerate up to $1500 \mathrm{mg} \mathrm{L}^{-1}$ fluorides and reduce fluoride, which may provide an opportunity to introduce a new bioremediation technique $[227,231]$.

In bacterial-based bioremediation, maintaining high bacterial biomass for enhancing adsorption and survival of bacterial species in fluoride water is the most significant factor to be considered. This can be achieved by immobilizing bacterial cells $[228,229]$. In the 
experiment, bacterial cells were immobilized on different media, and more than $90 \%$ efficiencies were obtained $[229,230]$. This process can be further advanced via understanding the interactions between immobilized cells and fluoride ions at a molecular level, which can help to develop advanced genetically modified organisms. Su et al. [232] developed a biofilm reactor for simultaneous denitrification and removal of fluoride ions and calcium from water, and $>80 \%$ removal efficiency was found at alkaline $\mathrm{pH}$. A microbe isolated from potable water showed fluoride removal efficiency of $57.3 \%$ within $10 \mathrm{~h}$ in the batch optimization experiment [100].

\subsection{Phytoremediation}

The limitations of microbial usage in bioremediation are less use of bacterial sludge and its long-standing commitments [250]. On the other hand, the plant-based phytoremediation technique has several limitations, such as time consumption, growing with nonideal conditions, and the safe disposal of hyper-accumulating plants after harvesting [250]. Table 3 highlights different plant species and plant-based systems that can remove fluoride from contaminated water. Plant-based approaches to remediate fluoride from the environment have become an intense study area in recent years [213]. A number of plant-based systems have been investigated for fluoride remediation from contaminated water [213,251-253]. Khandare et al. [254] investigated four hydrophytes Canna indica, Epipremnum aureum, Cyperus alternifolius, and Cyperus rotundus. They found that Canna indica has more fluoride removal efficiency than the other three hydrophytes. Yadav found that the fluoride removal efficiencies of activated bagasse carbon of sugarcane, sawdust raw, and wheat straw raw were $56.4 \%, 49.8 \%$, and $40.2 \%$, respectively, for an aqueous solution of $5 \mathrm{mg} / \mathrm{L}$ fluorides at $\mathrm{pH} 6.0$, with the contact period of $60 \mathrm{~min}$ and a dose of $4 \mathrm{~g} / \mathrm{L}$.

Table 3. Fluoride removal from contaminated water using plant-based systems.

\begin{tabular}{|c|c|c|c|c|}
\hline Plant Species & $\begin{array}{c}\text { Fluoride Removal } \\
\text { Efficiency (\%) }\end{array}$ & Contact Time & $\begin{array}{l}\text { Initial Conc. } \\
\left(\mathrm{mg} \mathrm{L} \mathrm{L}^{-1}\right)\end{array}$ & References \\
\hline Tulsi (Ocimum sanctum) leaves & 68.4 & $22.6 \mathrm{~min}$ & 6.6 & [255] \\
\hline Canna indica & 95 & 10 days & 10 & {$[256]$} \\
\hline Epipremnum aureum & 52 & 10 days & 10 & [256] \\
\hline Cyperus alternifolius & 65 & 10 days & 10 & [256] \\
\hline Cyperus rotundus & 56 & 10 days & 10 & [256] \\
\hline Landoltia punctata & 21 & 10 days & 5 & {$[257]$} \\
\hline Nerium oleander & 92 & 15 days & 10 & [254] \\
\hline Portulaca oleracea & 80 & 15 days & 10 & {$[254]$} \\
\hline Portulaca oleracea & 73 & 15 days & 10 & [254] \\
\hline Camellia japonica & 40 & 21 days & 4 & [258] \\
\hline Pittosporum tobira & 7.5 & 21 days & 4 & [258] \\
\hline Saccharum officinarum & 15 & 21 days & 4 & [258] \\
\hline Pistia stratiotes & 19.87 & 10 days & 3 & [259] \\
\hline Spirodela polyrhiza & 19.23 & 10 days & 3 & [259] \\
\hline Eichhornia crassipes & 12.71 & 10 days & 3 & {$[259]$} \\
\hline Grape pomace & 96.13 & $60 \mathrm{~min}$ & 19.91 & {$[260]$} \\
\hline Residue of tea & 90 & $60-90 \mathrm{~min}$ & 4 & [261] \\
\hline Rice husk & 75 & $120 \mathrm{~min}$ & 10 & [262] \\
\hline Tamarind seed & 90 & 1 day & 5 & [263] \\
\hline Flower patel biomass of Senna auriculata L. & 80 & $90 \mathrm{~min}$ & 5 & {$[264]$} \\
\hline Active carbon derived from barks of Vitex negundo & 99.2 & $50 \mathrm{~min}$ & 5 & {$[265]$} \\
\hline Ficus benghalensis leaf & 92.2 & $90 \mathrm{~min}$ & 5 & {$[266]$} \\
\hline $\begin{array}{l}\text { Activated carbon derived from iron infused Pisum } \\
\text { sativum peel }\end{array}$ & 99 & $420 \mathrm{~min}$ & 5 & {$[267]$} \\
\hline Active carbon derived from the barks of Ficus racemosa & 88 & $60 \mathrm{~min}$ & 5 & [268] \\
\hline \multirow[t]{3}{*}{ Ficus glomerata bark-developed biosorbent } & 90 & $120 \mathrm{~min}$ & 5 & [269] \\
\hline & 98.08 & & 2 & \\
\hline & 87.71 & & 4 & \\
\hline \multirow[t]{3}{*}{ Wattle humus biosorbent } & 75.55 & $40 \mathrm{~min}$ & 6 & [270] \\
\hline & 66.86 & & 8 & \\
\hline & 59.89 & & 10 & \\
\hline Cofee grounds & 56.67 & $90 \mathrm{~min}$ & 3 & [271] \\
\hline Eichhornia crassipes & 57.8 & $72 \mathrm{~h}$ & 10 & {$[272]$} \\
\hline Lemna major & 98.83 & $72 \mathrm{~h}$ & 30 & {$[272]$} \\
\hline Activated bagasse carbon of sugarcane & 56.4 & $60 \mathrm{~min}$ & 5 & {$[273]$} \\
\hline Sawdust raw & 49.8 & $60 \mathrm{~min}$ & 5 & {$[273]$} \\
\hline Wheat straw raw & 40.2 & $60 \mathrm{~min}$ & 5 & [273] \\
\hline
\end{tabular}


With the ubiquitous presence and ability to take nutrients for growth from wastewater, algae help in decreasing pollution and contribute to environmental clean-up [105,236,243]. This algal biomass is rich in various nutrients such as hydrocarbon, lipids, and polysaccharides and hence can be used as feedstock to produce green fuels such as bioethanol and biodiesel $[274,275]$. For fluoride removal from soil and water, physicochemical and microbial remediation work has been done, but very little work using microalgae has been reported [276-278]. The algae cell wall is composed of alginate, which has various acidic functional groups and aids in heavy metal adsorption. As carboxylic acid binds with metallic ions, such as calcium, it stabilizes alginate, increasing adsorption capacity [279]. Mukherjee et al. [238] have observed the enhanced fluoride adsorption due to calcium pretreatment, attributed to more positive charges on algae surface and thus adsorption of anionic fluoride compared to non-calcium-pretreated biomass. The variation in adsorption capacity at different fluoride concentrations was observed using viable and nonviable cells of Spirogyra sp. in an aqueous phase [234,235]. Mittal et al. [237] used living encapsulated blue-green algae Phormidium sp. for fluoride sorption from aqueous media and found that maximum sorption of up to $60 \%$ was achieved. Using Padina sp. as an eco-friendly sorbent and one factor at a time strategy, the maximum fluoride adsorption efficiency was $85.95 \%$ at optimum $\mathrm{pH} 7$, initial fluoride concentration $2 \mathrm{~g} \mathrm{~L}^{-1}$, residence time $60 \mathrm{~min}$, and biosorbent dose of $30 \mathrm{~g} \mathrm{~L}^{-1}$ [238].

\subsection{Mycoremediation}

In this method, fungal biomass and its enzymes were used for fluoride remediation. Selected examples are listed in Table 2. Fungal biomasses are ecologically and metabolically diverse organisms and can degrade various contaminants [243]. These can form an extended mycelial structure that penetrates inside the host cell to absorb water and nutrients. The intracellular and extracellular enzymatic composition of fungal biomass enables them to degrade a wide range of pollutants and decrease their associated risk [243]. In a study, the fluoride remediation ability of dried and crushed powder of fungi Pleurotus sp. was used in the aqueous phase $[239,241]$. Defluoridation of more than $50 \%$ was achieved, and isotherm data fit well with the Langmuir model, indicating monolayer adsorption on a homogeneous surface. In another study, pretreatment of fungal biomass with calcium ion improved defluoridation capacity due to forming positive charge surfaces that attract negative charge anions [240]. Microalgal biomass is an effective tool for fluoride removal [279]. Annadurai et al. [106] observed that dead fungal biomass could adsorb fluoride more efficiently in a column experiment, having an adsorption capacity of $89 \%$, and may have the potential to remove fluoride from an aqueous solution altogether.

\section{Summary, Conclusions, and Future Perspectives}

This review mainly focused on the discussion of bioaccumulation in plants and microbial approaches for fluoride remediation. Fluoride accumulation in plants is a significant risk, affecting their growth and development [196]. It enters into plants through water, soil, or leaves [191]. Plants may undergo biochemical, physiological, and molecular changes due to continuous fluoride exposure [209]. Many techniques have been used for fluoride remediation, such as coagulation, precipitation, ion exchange, membrane separation, electrodialysis, and adsorption $[9,57,58,66]$, though it requires high energy and skilled maintenance. Bioremediation is one of the significant approaches for the removal of fluoride from contaminated soil or water. Besides, the removal of toxic metals, including fluoride, through microorganisms has gained prominence. Microbe-based fluoride removal techniques are cost-effective, require less energy, and have simple operation methods [104]. Microbes can oxidize transition metals and also have the ability to dissolve heavy metals [280]. The ability of microbial remediation techniques to defluorinate the water using immobilized live or dead cells has been documented well in the literature. However, live cells could be a better option to make microbial remediation more effective, active, and growing because of properties like self-replenishment, adaptive nature in response 
to unfavorable conditions, and metal uptake as an energy source. Moreover, consortia, i.e., binary setups using microbes, should be used for removal purposes [103]. Efficient fluoride-degrading organisms should be emphasized to commercialize the fluoride remediation method [281]. Removing contaminated organisms from water bodies should also be an integral part of the bioremediation process [281]. There are some potential future perspectives that should be considered for further studies using the microbial remediation method for fluoride removal:

- Almost all technology usually requires a high cost and high energy consumption. Because there is very little information about the cost-effectiveness of the technologies, a quantitative discussion about cost-effectiveness should be further documented for future investigations.

- Due to organism viability requirements and inadequate fluoride resistance, microbial remediation can be considered for implications in fluoride-containing effluent in wastewater treatment facilities. However, microbial remediation techniques can still be integrated with wastewater treatment and management by trapping free fluoride ions in surface waters (via macrophytes) and preventing fluoride leaching in soil (via terrestrial plants), which can be transported to aquifer systems and other natural water bodies.

- Nanotechnology and microbe-based approaches should be promoted for biomass usage, and additional research should focus on fluoride bioaccumulation and fluoride tolerance in plants using omics and transgenic approaches. The identification and characterization of genes related to fluoride transporters, antioxidants, and stressresponsive genes for fluoride tolerance are required.

- Pollen growth and development at different fluoride concentrations in plants should be investigated.

- Most remediation techniques have only been developed at the laboratory scale, using synthetic solutions. However, a large quantity of fluoride is released through industrial activities, with critical effects on human health and the environment. So, more research should be conducted in the field or areas affected by fluoride contamination.

- It is seen that a specific adsorbent in the laboratory shows higher fluoride uptake in the batch experiment but fails in the investigation conducted in field conditions. As a result, choosing the appropriate technology and adsorbent is essential.

- Plants can be used for phytoremediation and perform well in fluoride uptake, and a safe and less expensive process should be encouraged for long-term research.

Supplementary Materials: The following are available online at https:/ / www.mdpi.com/article/10 .3390/ pr9122154/s1. Table S1: Summary of studies reporting high fluoride concentrations in Indian soil-water systems.

Author Contributions: Conceptualization, R.K., P.K.J. and P.K.G.; writing—original draft preparation, R.K., R.S., P.K.S., N.I., N.K. and P.K.; writing-review and editing, A.J., P.K.J., P.K.G., P.S., R.K.S., R.P.S., A.G. and P.V.V.P.; supervision, P.S.; visualization, P.K.J., P.KG., P.S. and P.V.V.P. All authors have read and agreed to the published version of the manuscript.

Funding: This work received no external funding.

Institutional Review Board Statement: Not applicable.

Informed Consent Statement: Not applicable.

Data Availability Statement: Data are presented in the manuscript.

Acknowledgments: All authors thank their organization for supporting their research activities. Authors would also thanks SYAHI for providing a communication platform.

Conflicts of Interest: The authors declare no conflict of interest. 


\section{References}

1. Singh, G.; Kumari, B.; Sinam, G.; Kumar, N.; Mallick, S. Fluoride distribution and contamination in the water, soil and plants continuum and its remedial technologies, an Indian perspective-A review. Environ. Pollut. 2018, 239, 95-108. [CrossRef]

2. Camargo, J.A.; Alonso, Á. Ecological and toxicological effects of inorganic nitrogen pollution in aquatic ecosystems: A global assessment. Environ. Int. 2006, 32, 831-849. [CrossRef]

3. Selinus, O.; Alloway, B.; Centeno, J.A.; Finkelman, R.B.; Fuge, R.; Lindh, U.; Smedley, P. Essentials of Medical Geology; Springer: Berlin/Heidelberg, Germany, 2016.

4. Hem, J.D. Study and Interpretation of the Chemical Characteristics of Natural Water; Department of the Interior, US Geological Survey: Washington, DC, USA, 1985; Volume 2254.

5. Pickering, W. The mobility of soluble fluoride in soils. Environ. Pollut. Ser. B Chem. Phys. 1985, 9, 281-308. [CrossRef]

6. Yadav, M.; Singh, G.; Jadeja, R. Fluoride Contamination in Groundwater, Impacts, and Their Potential Remediation Techniques. Groundw. Geochem. Pollut. Remediat. Methods 2021, 22-41. [CrossRef]

7. Handa, B. Geochemistry and genesis of Fluoride-Containing ground waters in india. Groundwater 1975, 13, 275-281. [CrossRef]

8. Churchill, H.; Rowley, R.; Martin, L. Flourine Content of Certain Vegetation in Western Pennsylvania Area. Anal. Chem. 1948, 20, 69-71. [CrossRef]

9. Gupta, S.; Deshpande, R.; Agarwal, M.; Raval, B. Origin of high fluoride in groundwater in the North Gujarat-Cambay region, India. Hydrogeol. J. 2005, 13, 596-605. [CrossRef]

10. Ali, S.; Thakur, S.K.; Sarkar, A.; Shekhar, S. Worldwide contamination of water by fluoride. Environ. Chem. Lett. 2016, 14, 291-315. [CrossRef]

11. Datta, P.; Deb, D.; Tyagi, S. Stable isotope (18O) investigations on the processes controlling fluoride contamination of groundwater. J. Contam. Hydrol. 1996, 24, 85-96. [CrossRef]

12. Bibi, S.; Kamran, M.A.; Sultana, J.; Farooqi, A. Occurrence and methods to remove arsenic and fluoride contamination in water. Environ. Chem. Lett. 2017, 15, 125-149. [CrossRef]

13. Hong, B.-D.; Joo, R.-N.; Lee, K.-S.; Lee, D.-S.; Rhie, J.-H.; Min, S.-W.; Song, S.-G.; Chung, D.-Y. Fluoride in soil and plant. Korean J. Agric. Sci. 2016, 43, 522-536. [CrossRef]

14. WHO. Guidelines for Drinking-Water Quality; World Health Organization: Geneva, Switzerland, 2004 ; Volume 1.

15. BIS. Drinking Water-Specification B.S.10500; Bureau of Indian Standard: New Delhi, India, 2012. Available online: http:/ /cgwb.gov. in/Documents/WQ-standards.pdf (accessed on 20 October 2021).

16. WHO. Surveillance and control of community supplies. In Surveillance and Control of Community Supplies; WHO: Geneva, Switzerland, 1997; p. 238.

17. Raj, D.; Shaji, E. Fluoride contamination in groundwater resources of Alleppey, southern India. Geosci. Front. 2017, 8, 117-124. [CrossRef]

18. Maheshwari, R. Fluoride in drinking water and its removal. J. Hazard. Mater. 2006, 137, 456-463. [CrossRef]

19. Banks, D.; Frengstad, B.; Midtgård, A.K.; Krog, J.R.; Strand, T. The chemistry of Norwegian groundwaters: I. The distribution of radon, major and minor elements in 1604 crystalline bedrock groundwaters. Sci. Total Environ. 1998, 222, 71-91. [CrossRef]

20. Chae, G.-T.; Yun, S.-T.; Mayer, B.; Kim, K.-H.; Kim, S.-Y.; Kwon, J.-S.; Kim, K.; Koh, Y.-K. Fluorine geochemistry in bedrock groundwater of South Korea. Sci. Total Environ. 2007, 385, 272-283. [CrossRef] [PubMed]

21. Dissanayake, C. The fluoride problem in the ground water of Sri Lanka-Environmental management and health. Int. J. Environ. Stud. 1991, 38, 137-155. [CrossRef]

22. Gaciri, S.; Davies, T. The occurrence and geochemistry of fluoride in some natural waters of Kenya. J. Hydrol. 1993, 143, 395-412. [CrossRef]

23. Mirlean, N.; Roisenberg, A. Fluoride distribution in the environment along the gradient of a phosphate-fertilizer production emission (Southern Brazil). Environ. Geochem. Health 2007, 29, 179-187. [CrossRef] [PubMed]

24. Oruc, N. Problems of high fluoride waters in Turkey. Chin. J. Geochem. 2003, 25, 55. [CrossRef]

25. Amini, M.; Mueller, K.; Abbaspour, K.C.; Rosenberg, T.; Afyuni, M.; Møller, K.N.; Sarr, M.; Johnson, C.A. Statistical modeling of global geogenic fluoride contamination in groundwaters. Environ. Sci. Technol. 2008, 42, 3662-3668. [CrossRef] [PubMed]

26. Malago, J.; Makoba, E.; Muzuka, A.N. Fluoride levels in surface and groundwater in Africa: A review. Am. J. Water Sci. Eng. 2017, 3, 1-17. [CrossRef]

27. Nair, K.; Manji, F.; Gitonga, J. The occurrence and distribution of fluoride in groundwaters of Kenya. East Afr. Med. J. 1984, 61, 503-512.

28. Akpata, E.S.; Danfillo, I.; Otoh, E.; Mafeni, J. Geographical mapping of fluoride levels in drinking water sources in Nigeria. Afr. Health Sci. 2009, 9, 227-233. [PubMed]

29. Rao, N.S.; Devadas, D.J. Fluoride incidence in groundwater in an area of Peninsular India. Environ. Geol. 2003, 45, $243-251$. [CrossRef]

30. Subba Rao, N. Groundwater quality: Focus on fluoride concentration in rural parts of Guntur district, Andhra Pradesh, India. Hydrol. Sci. J. 2003, 48, 835-847. [CrossRef]

31. Ramanaiah, S.; Mohan, S.V.; Rajkumar, B.; Sarma, P. Monitoring of fluoride concentration in ground water of Prakasham district in India: Correlation with physico-chemical parameters. J. Environ. Sci. Eng. 2006, 48, 129. 
32. Rao, N.S. Fluoride in groundwater, Varaha River Basin, Visakhapatnam District, Andhra Pradesh, India. Environ. Monit. Assess. 2009, 152, 47-60. [CrossRef]

33. Arveti, N.; Sarma, M.; Aitkenhead-Peterson, J.; Sunil, K. Fluoride incidence in groundwater: A case study from Talupula, Andhra Pradesh, India. Environ. Monit. Assess. 2011, 172, 427-443. [CrossRef] [PubMed]

34. Das, B.; Talukdar, J.; Sarma, S.; Gohain, B.; Dutta, R.K.; Das, H.B.; Das, S.C. Fluoride and other inorganic constituents in groundwater of Guwahati, Assam, India. Curr. Sci. 2003, 85, 657-661.

35. Dutta, R.; Saikia, G.; Das, B.; Bezbaruah, C.; Das, H.; Dube, S. Fluoride contamination in groundwater of Central Assam, India. Asian J. Water Environ. Pollut. 2006, 3, 93-100.

36. Ray, D.; Rao, R.R.; Bhoi, A.; Biswas, A.; Ganguly, A.; Sanyal, P. Physico-chemical quality of drinking water in Rohtas district of Bihar. Environ. Monit. Assess. 2000, 61, 387-398. [CrossRef]

37. Beg, M.; Srivastav, S.; Carranza, E.; De Smeth, J. High fluoride incidence in groundwater and its potential health effects in parts of Raigarh District, Chhattisgarh, India. Curr. Sci. 2011, 100, 750-754.

38. Srivastava, S.K.; Ramanathan, A. Geochemical assessment of groundwater quality in vicinity of Bhalswa landfill, Delhi, India, using graphical and multivariate statistical methods. Environ. Geol. 2008, 53, 1509-1528. [CrossRef]

39. Salve, P.; Maurya, A.; Kumbhare, P.; Ramteke, D.; Wate, S. Assessment of groundwater quality with respect to fluoride. Bull. Environ. Contam. Toxicol. 2008, 81, 289. [CrossRef]

40. Dhiman, S.; Keshari, A.K. Hydrogeochemical evaluation of high-fluoride groundwaters: A case study from Mehsana District, Gujarat, India. Hydrol. Sci. J. 2006, 51, 1149-1162. [CrossRef]

41. Kaushik, A.; Kumar, K.; Sharma, I.; Sharma, H. Groundwater quality assessment in different land-use areas of Faridabad and Rohtak cities of Haryana using deviation index. J. Environ. Biol. 2004, 25, 173-180.

42. Yadav, J.; Lata, S.; Kataria, S.K.; Kumar, S. Fluoride distribution in groundwater and survey of dental fluorosis among school children in the villages of the Jhajjar District of Haryana, India. Environ. Geochem. Health 2009, 31, 431-438. [CrossRef]

43. Ravindra, K.; Garg, V.K. Distribution of fluoride in groundwater and its suitability assessment for drinking purpose. Int. J. Environ. Health Res. 2006, 16, 163-166. [CrossRef]

44. Bishnoi, M.; Arora, S. Potable groundwater quality in some villages of Haryana, India: Focus on fluoride. J. Environ. Biol. 2007, $28,291$.

45. Ramakrishnaiah, C.; Sadashivaiah, C.; Ranganna, G. Assessment of water quality index for the groundwater in Tumkur Taluk, Karnataka State, India. J. Chem. 2009, 6, 523-530. [CrossRef]

46. Mamatha, P.; Rao, S.M. Geochemistry of fluoride rich groundwater in Kolar and Tumkur Districts of Karnataka. Environ. Earth Sci. 2010, 61, 131-142. [CrossRef]

47. Shaji, E.; Viju, J.; Thambi, D. High fluoride in groundwater of Palghat District, Kerala. Curr. Sci. 2007, 92, $240-245$.

48. Avtar, R.; Kumar, P.; Surjan, A.; Gupta, L.; Roychowdhury, K. Geochemical processes regulating groundwater chemistry with special reference to nitrate and fluoride enrichment in Chhatarpur area, Madhya Pradesh, India. Environ. Earth Sci. 2013, 70, 1699-1708. [CrossRef]

49. Madhnure, P.; Sirsikar, D.; Tiwari, A.; Ranjan, B.; Malpe, D. Occurrence of fluoride in the groundwaters of Pandharkawada area, Yavatmal district, Maharashtra, India. Curr. Sci. 2007, 675-679.

50. Dey, R.; Swain, S.; Mishra, S.; Sharma, P.; Patnaik, T.; Singh, V.; Dehury, B.; Jha, U.; Patel, R. Hydrogeochemical processes controlling the high fluoride concentration in groundwater: A case study at the Boden block area, Orissa, India. Environ. Monit. Assess. 2012, 184, 3279-3291. [CrossRef]

51. Kundu, N.; Panigrahi, M.; Tripathy, S.; Munshi, S.; Powell, M.; Hart, B. Geochemical appraisal of fluoride contamination of groundwater in the Nayagarh District of Orissa, India. Environ. Geol. 2001, 41, 451-460. [CrossRef]

52. Kumar, M.; Kumari, K.; Ramanathan, A.; Saxena, R. A comparative evaluation of groundwater suitability for irrigation and drinking purposes in two intensively cultivated districts of Punjab, India. Environ. Geol. 2007, 53, 553-574. [CrossRef]

53. Singh, C.K.; Mukherjee, S. Aqueous geochemistry of fluoride enriched groundwater in arid part of Western India. Environ. Sci. Pollut. Res. 2015, 22, 2668-2678. [CrossRef]

54. Arif, M.; Hussain, I.; Hussain, J.; Sharma, S.; Kumar, S. Fluoride in the drinking water of Nagaur Tehsil of Nagaur district, Rajasthan, India. Bull. Environ. Contam. Toxicol. 2012, 88, 870-875. [CrossRef]

55. Vikas, C.; Kushwaha, R.; Ahmad, W.; Prasannakumar, V.; Reghunath, R. Genesis and geochemistry of high fluoride bearing groundwater from a semi-arid terrain of NW India. Environ. Earth Sci. 2013, 68, 289-305. [CrossRef]

56. Suthar, S.; Garg, V.K.; Jangir, S.; Kaur, S.; Goswami, N.; Singh, S. Fluoride contamination in drinking water in rural habitations of Northern Rajasthan, India. Environ. Monit. Assess. 2008, 145, 1-6. [CrossRef] [PubMed]

57. Hussain, I.; Arif, M.; Hussain, J. Fluoride contamination in drinking water in rural habitations of Central Rajasthan, India. Environ. Monit. Assess. 2012, 184, 5151-5158. [CrossRef]

58. Singh, C.K.; Rina, K.; Singh, R.; Shashtri, S.; Kamal, V.; Mukherjee, S. Geochemical modeling of high fluoride concentration in groundwater of Pokhran area of Rajasthan, India. Bull. Environ. Contam. Toxicol. 2011, 86, 152-158. [CrossRef]

59. Vikas, C.; Kushwaha, R.; Pandit, M. Hydrochemical status of groundwater in district Ajmer (NW India) with reference to fluoride distribution. J. Geol. Soc. India 2009, 73, 773-784. [CrossRef]

60. Arumugam, K.; Elangovan, K. Hydrochemical characteristics and groundwater quality assessment in Tirupur region, Coimbatore district, Tamil Nadu, India. Environ. Geol. 2009, 58, 1509-1520. [CrossRef] 
61. Singaraja, C.; Chidambaram, S.; Anandhan, P.; Prasanna, M.V.; Thivya, C.; Thilagavathi, R. A study on the status of fluoride ion in groundwater of coastal hard rock aquifers of south India. Arab. J. Geosci. 2013, 6, 4167-4177. [CrossRef]

62. Srinivasamoorthy, K.; Vijayaraghavan, K.; Vasanthavigar, M.; Sarma, S.; Chidambaram, S.; Anandhan, P.; Manivannan, R. Assessment of groundwater quality with special emphasis on fluoride contamination in crystalline bed rock aquifers of Mettur region, Tamilnadu, India. Arab. J. Geosci. 2012, 5, 83-94. [CrossRef]

63. Chidambaram, S.; Prasad, M.B.K.; Manivannan, R.; Karmegam, U.; Singaraja, C.; Anandhan, P.; Prasanna, M.V.; Manikandan, S. Environmental hydrogeochemistry and genesis of fluoride in groundwaters of Dindigul district, Tamilnadu (India). Environ. Earth Sci. 2013, 68, 333-342. [CrossRef]

64. Magesh, N.; Krishnakumar, S.; Chandrasekar, N.; Soundranayagam, J.P. Groundwater quality assessment using WQI and GIS techniques, Dindigul district, Tamil Nadu, India. Arab. J. Geosci. 2013, 6, 4179-4189. [CrossRef]

65. Srinivasamoorthy, K.; Nanthakumar, C.; Vasanthavigar, M.; Vijayaraghavan, K.; Rajivgandhi, R.; Chidambaram, S.; Anandhan, P.; Manivannan, R.; Vasudevan, S. Groundwater quality assessment from a hard rock terrain, Salem district of Tamilnadu, India. Arab. J. Geosci. 2011, 4, 91-102. [CrossRef]

66. Dar, M.A.; Sankar, K.; Dar, I.A. Fluorine contamination in groundwater: A major challenge. Environ. Monit. Assess. 2011, 173, 955-968. [CrossRef]

67. Karthikeyan, K.; Nanthakumar, K.; Velmurugan, P.; Tamilarasi, S.; Lakshmanaperumalsamy, P. Prevalence of certain inorganic constituents in groundwater samples of Erode district, Tamilnadu, India, with special emphasis on fluoride, fluorosis and its remedial measures. Environ. Monit. Assess. 2010, 160, 141-155. [CrossRef] [PubMed]

68. Narsimha, A.; Sudarshan, V. Contamination of fluoride in groundwater and its effect on human health: A case study in hard rock aquifers of Siddipet, Telangana State, India. Appl. Water Sci. 2017, 7, 2501-2512. [CrossRef]

69. Reddy, A.; Reddy, D.; Rao, P.; Prasad, K.M. Hydrogeochemical characterization of fluoride rich groundwater of Wailpalli watershed, Nalgonda District, Andhra Pradesh, India. Environ. Monit. Assess. 2010, 171, 561-577. [CrossRef] [PubMed]

70. Brindha, K.; Rajesh, R.; Murugan, R.; Elango, L. Fluoride contamination in groundwater in parts of Nalgonda District, Andhra Pradesh, India. Environ. Monit. Assess. 2011, 172, 481-492. [CrossRef]

71. Adimalla, N.; Venkatayogi, S. Mechanism of fluoride enrichment in groundwater of hard rock aquifers in Medak, Telangana State, South India. Environ. Earth Sci. 2017, 76, 45. [CrossRef]

72. Asadi, S.; Vuppala, P.; Reddy, M.A. Remote sensing and GIS techniques for evaluation of groundwater quality in municipal corporation of Hyderabad (Zone-V), India. Int. J. Environ. Res. Public Health 2007, 4, 45-52. [CrossRef]

73. Sujatha, D. Fluoride levels in the groundwater of the south-eastern part of Ranga Reddy district, Andhra Pradesh, India. Environ. Geol. 2003, 44, 587-591. [CrossRef]

74. Sharma, B.; Agrawal, J.; Gupta, A.K. Emerging challenge: Fluoride contamination in groundwater in Agra District, Uttar Pradesh. Asian J. Exp. Biol. Sci. 2011, 2, 131-134.

75. Sankararamakrishnan, N.; Sharma, A.K.; Iyengar, L. Contamination of nitrate and fluoride in ground water along the Ganges Alluvial Plain of Kanpur district, Uttar Pradesh, India. Environ. Monit. Assess. 2008, 146, 375-382. [CrossRef]

76. Raju, N.J.; Dey, S.; Das, K. Fluoride contamination in groundwaters of Sonbhadra district, Uttar Pradesh, India. Curr. Sci. 2009, 96, 979-985.

77. Raju, N.J.; Dey, S.; Gossel, W.; Wycisk, P. Fluoride hazard and assessment of groundwater quality in the semi-arid Upper Panda River basin, Sonbhadra district, Uttar Pradesh, India. Hydrol. Sci. J. 2012, 57, 1433-1452. [CrossRef]

78. Gupta, S.; Banerjee, S.; Saha, R.; Datta, J.; Mondal, N. Fluoride geochemistry of groundwater in Nalhati-1 block of the Birbhum district, West Bengal, India. Fluoride 2006, 39, 318.

79. Kundu, M.C.; Mandal, B. Assessment of potential hazards of fluoride contamination in drinking groundwater of an intensively cultivated district in West Bengal, India. Environ. Monit. Assess. 2009, 152, 97-103. [CrossRef]

80. Mondal, D.; Gupta, S.; Reddy, D.; Nagabhushanam, P. Geochemical controls on fluoride concentrations in groundwater from alluvial aquifers of the Birbhum district, West Bengal, India. J. Geochem. Explor. 2014, 145, 190-206. [CrossRef]

81. Genxu, W.; Guodong, C. Fluoride distribution in water and the governing factors of environment in arid North-West China. J. Arid Environ. 2001, 49, 601-614. [CrossRef]

82. Apambire, W.; Boyle, D.; Michel, F. Geochemistry, genesis, and health implications of fluoriferous groundwaters in the upper regions of Ghana. Environ. Geol. 1997, 33, 13-24. [CrossRef]

83. Roy, S.; Dass, G. Fluoride contamination in drinking water-A review. Resour. Environ. 2013, 3, 53-58. [CrossRef]

84. Bhatnagar, A.; Kumar, E.; Sillanpää, M. Fluoride removal from water by adsorption—A review. Chem. Eng. J. 2011, 171, 811-840. [CrossRef]

85. Jha, P.K.; Tripathi, P. Arsenic and fluoride contamination in groundwater: A review of global scenarios with special reference to India. Groundw. Sustain. Dev. 2021, 13, 100576. [CrossRef]

86. Maity, J.P.; Hsu, C.-M.; Lin, T.-J.; Lee, W.-C.; Bhattacharya, P.; Bundschuh, J.; Chen, C.-Y. Removal of fluoride from water through bacterial-surfactin mediated novel hydroxyapatite nanoparticle and its efficiency assessment: Adsorption isotherm, adsorption kinetic and adsorption thermodynamics. Environ. Nanotechnol. Monit. Manag. 2018, 9, 18-28. [CrossRef]

87. Kumar, R.; Sharma, P.; Aman, A.K.; Singh, R.K. Equilibrium sorption of fluoride on the activated alumina in aqueous solution. Desalination Water Treat. 2020, 197, 224-236. [CrossRef] 
88. Singh, G.; Kumar, B.; Sen, P.; Majumdar, J. Removal of fluoride from spent pot liner leachate using ion exchange. Water Environ. Res. 1999, 71, 36-42. [CrossRef]

89. Saha, S. Treatment of aqueous effluent for fluoride removal. Water Res. 1993, 27, 1347-1350. [CrossRef]

90. Reardon, E.J.; Wang, Y. A limestone reactor for fluoride removal from wastewaters. Environ. Sci. Technol. 2000, 34, $3247-3253$. [CrossRef]

91. Amor, Z.; Bariou, B.; Mameri, N.; Taky, M.; Nicolas, S.; Elmidaoui, A. Fluoride removal from brackish water by electrodialysis. Desalination 2001, 133, 215-223. [CrossRef]

92. Mameri, N.; Lounici, H.; Belhocine, D.; Grib, H.; Piron, D.; Yahiat, Y. Defluoridation of Sahara water by small plant electrocoagulation using bipolar aluminium electrodes. Sep. Purif. Technol. 2001, 24, 113-119. [CrossRef]

93. Hichour, M.; Persin, F.; Sandeaux, J.; Gavach, C. Fluoride removal from waters by Donnan dialysis. Sep. Purif. Technol. 1999, 18, 1-11. [CrossRef]

94. Barathi, M.; Kumar, A.S.K.; Rajesh, N. Impact of fluoride in potable water-An outlook on the existing defluoridation strategies and the road ahead. Coord. Chem. Rev. 2019, 387, 121-128. [CrossRef]

95. Jayashreea, D.E.; Poojaa, G.; Kumara, P.S.; Prasannamedhaa, G. A review on fluoride: Treatment strategies and scope for further research. Desalination Water Treat. 2020, 200, 167-186. [CrossRef]

96. Tripathy, S.S.; Bersillon, J.-L.; Gopal, K. Removal of fluoride from drinking water by adsorption onto alum-impregnated activated alumina. Sep. Purif. Technol. 2006, 50, 310-317. [CrossRef]

97. Karthikeyan, G.; Ilango, S.S. Fluoride sorption using Morringa Indica-based activated carbon. J. Environ. Health Sci. Eng. 2007, 4, 21-28.

98. Sarkar, M.; Banerjee, A.; Pramanick, P.P.; Sarkar, A.R. Design and operation of fixed bed laterite column for the removal of fluoride from water. Chem. Eng. J. 2007, 131, 329-335. [CrossRef]

99. Nigussie, W.; Zewge, F.; Chandravanshi, B. Removal of excess fluoride from water using waste residue from alum manufacturing process. J. Hazard. Mater. 2007, 147, 954-963. [CrossRef] [PubMed]

100. Shanker, A.S.; Srinivasulu, D.; Pindi, P.K. A study on bioremediation of fluoride-contaminated water via a novel bacterium Acinetobacter sp. (GU566361) isolated from potable water. Results Chem. 2020, 2, 100070. [CrossRef]

101. Kleinübing, S.; Da Silva, E.; Da Silva, M.; Guibal, E. Equilibrium of Cu (II) and Ni (II) biosorption by marine alga Sargassum filipendula in a dynamic system: Competitiveness and selectivity. Bioresour. Technol. 2011, 102, 4610-4617. [CrossRef] [PubMed]

102. Chouhan, S.; Tuteja, U.; Flora, S. Isolation, identification and characterization of fluoride resistant bacteria: Possible role in bioremediation. Appl. Biochem. Microbiol. 2012, 48, 43-50. [CrossRef]

103. Juwarkar, A.A.; Yadav, S.K. Bioaccumulation and Biotransformation of Heavy Metals. In Bioremediation Technology: Recent Advances; Fulekar, M.H., Ed.; Springer: Dordrecht, The Netherlands, 2010; pp. 266-284.

104. Mukherjee, S.; Sahu, P.; Halder, G. Microbial remediation of fluoride-contaminated water via a novel bacterium Providencia vermicola (KX926492). J. Environ. Manag. 2017, 204, 413-423. [CrossRef]

105. Biswas, G.; Thakurta, S.G.; Chakrabarty, J.; Adhikari, K.; Dutta, S. Evaluation of fluoride bioremediation and production of biomolecules by living cyanobacteria under fluoride stress condition. Ecotoxicol. Environ. Saf. 2018, 148, 26-36. [CrossRef] [PubMed]

106. Annadurai, S.T.; Arivalagan, P.; Sundaram, R.; Mariappan, R.; Munusamy, A.P. Batch and column approach on biosorption of fluoride from aqueous medium using live, dead and various pretreated Aspergillus niger (FS18) biomass. Surf. Interfaces 2019, 15, 60-69. [CrossRef]

107. Bera, B.; Ghosh, A. Fluoride dynamics in hydrogeological diversity and Fluoride Contamination Index mapping: A correlation study of North Singbhum Craton, India. Arab. J. Geosci. 2019, 12, 1-15. [CrossRef]

108. Hanse, A.; Chabukdhara, M.; Baruah, S.G.; Boruah, H.; Gupta, S.K. Fluoride contamination in groundwater and associated health risks in Karbi Anglong District, Assam, Northeast India. Environ. Monit. Assess. 2019, 191, 1-17. [CrossRef] [PubMed]

109. Amiri, V.; Berndtsson, R. Fluoride occurrence and human health risk from groundwater use at the west coast of Urmia Lake, Iran. Arab. J. Geosci. 2020, 13, 1-23. [CrossRef]

110. Yidana, S.M.; Ophori, D.; Banoeng-Yakubo, B.; Samed, A.A. A factor model to explain the hydrochemistry and causes of fluoride enrichment in groundwater from the middle Voltaian sedimentary aquifers in the northern region, Ghana. ARPN J. Eng. Appl. Sci. 2012, 7, 50-68.

111. Hossain, M.; Patra, P.K. Hydrogeochemical characterisation and health hazards of fluoride enriched groundwater in diverse aquifer types. Environ. Pollut. 2020, 258, 113646. [CrossRef] [PubMed]

112. Onipe, T.; Edokpayi, J.N.; Odiyo, J.O. A review on the potential sources and health implications of fluoride in groundwater of Sub-Saharan Africa. J. Environ. Sci. Health Part A 2020, 55, 1078-1093. [CrossRef] [PubMed]

113. Luo, W.; Gao, X.; Zhang, X. Geochemical processes controlling the groundwater chemistry and fluoride contamination in the Yuncheng Basin, China-An area with complex hydrogeochemical conditions. PLoS ONE 2018, 13, e0199082. [CrossRef] [PubMed]

114. Mikkonen, H.G.; van de Graaff, R.; Mikkonen, A.T.; Clarke, B.O.; Dasika, R.; Wallis, C.J.; Reichman, S.M. Environmental and anthropogenic influences on ambient background concentrations of fluoride in soil. Environ. Pollut. 2018, 242, 1838-1849. [CrossRef] [PubMed] 
115. Kaur, L.; Rishi, M.S.; Siddiqui, A.U. Deterministic and probabilistic health risk assessment techniques to evaluate non-carcinogenic human health risk (NHHR) due to fluoride and nitrate in groundwater of Panipat, Haryana, India. Environ. Pollut. 2020, 259, 113711. [CrossRef] [PubMed]

116. Yu, Y.-Q.; Cui, S.-F.; Fan, R.-J.; Fu, Y.-Z.; Liao, Y.-L.; Yang, J.-Y. Distribution and superposed health risk assessment of fluorine co-effect in phosphorous chemical industrial and agricultural sources. Environ. Pollut. 2020, 262, 114249. [CrossRef]

117. Brindha, K.; Elango, L. Fluoride in groundwater: Causes, implications and mitigation measures. Fluoride Prop. Appl. Environ. Manag. 2011, 1, 111-136.

118. Masood, N.; Hudson-Edwards, K.A.; Farooqi, A. Groundwater nitrate and fluoride profiles, sources and health risk assessment in the coal mining areas of Salt Range, Punjab Pakistan. Environ. Geochem. Health 2021, 1-14. [CrossRef]

119. Edmunds, W.M.; Smedley, P.L. Fluoride in natural waters. In Essentials of Medical Geology; Springer: Berlin/Heidelberg, Germany, 2013; pp. 311-336.

120. Jabal, M.S.A.; Abustan, I.; Rozaimy, M.R.; Al-Najar, H. Fluoride enrichment in groundwater of semi-arid urban area: Khan Younis City, southern Gaza Strip (Palestine). J. Afr. Earth Sci. 2014, 100, 259-266. [CrossRef]

121. Ahmed, A.A. Fluoride in Quaternary groundwater aquifer, Nile Valley, Luxor, Egypt. Arab. J. Geosci. 2014, 7, 3069-3083. [CrossRef]

122. Ayoob, S.; Gupta, A.K. Fluoride in drinking water: A review on the status and stress effects. Crit. Rev. Environ. Sci. Technol. 2006, 36, 433-487. [CrossRef]

123. Battaleb-Looie, S.; Moore, F.; Jafari, H.; Jacks, G.; Ozsvath, D. Hydrogeochemical evolution of groundwaters with excess fluoride concentrations from Dashtestan, South of Iran. Environ. Earth Sci. 2012, 67, 1173-1182. [CrossRef]

124. Battaleb-Looie, S.; Moore, F.; Jacks, G.; Ketabdari, M.R. Geological sources of fluoride and acceptable intake of fluoride in an endemic fluorosis area, southern Iran. Environ. Geochem. Health 2012, 34, 641-650. [CrossRef]

125. Dehbandi, R.; Moore, F.; Keshavarzi, B.; Abbasnejad, A. Fluoride hydrogeochemistry and bioavailability in groundwater and soil of an endemic fluorosis belt, central Iran. Environ. Earth Sci. 2017, 76, 177. [CrossRef]

126. Ibrahim, M.; Asimrasheed, M.; Sumalatha, M.; Prabhakar, P. Effects of fluoride contents in ground water: A review. Int. J. Pharm. Appl. 2011, 2, 128-134.

127. Buzalaf, M.A.R.; Whitford, G.M. Fluoride metabolism. In Fluoride and the Oral Environment; Buzalaf, M.A.R., Ed.; Monogr Oral Science Basel, Karger: Basel, Switzerland, 2011; Volume 22, pp. 20-36.

128. Dhar, V.; Bhatnagar, M. Physiology and toxicity of fluoride. Indian J. Dent. Res. 2009, 20, 350. [CrossRef]

129. Mellberg, J.R.; Ripa, L.W.; Leske, G.S. Fluorido in preventive dentistryTheory and clinical applications. Kerman Univ. Med. Sci. 1983, 1, 290.

130. Yadav, A.K.; Kaushik, C.P.; Haritash, A.K.; Singh, B.; Raghuvanshi, S.P.; Kansal, A. Determination of exposure and probable ingestion of fluoride through tea, toothpaste, tobacco and pan masala. J. Hazard. Mater. 2007, 142, 77-80. [CrossRef] [PubMed]

131. Ruan, J.; Ma, L.; Shi, Y.; Han, W. The impact of $\mathrm{pH}$ and calcium on the uptake of fluoride by tea plants (Camellia sinensis L.). Ann. Bot. 2004, 93, 97-105. [CrossRef]

132. Whitford, G.M. The Metabolism and Toxicity of Fluoride; Karger Publishers: Basel, Switzerland, 1996.

133. Harrison, P.T. Fluoride in water: A UK perspective. J. Fluor. Chem. 2005, 126, 1448-1456. [CrossRef]

134. Barbier, O.; Arreola-Mendoza, L.; Del Razo, L.M. Molecular mechanisms of fluoride toxicity. Chem. Biol. Interact. 2010, 188, 319-333. [CrossRef]

135. Maritim, A.; Sanders, R.; Watkins, J., 3rd. Oxidative stress and diabetic complications: A review. J. Biochem. Mol. Toxic 2003, 17, 24-38. [CrossRef]

136. Islam, M.; Patel, R. Thermal activation of basic oxygen furnace slag and evaluation of its fluoride removal efficiency. Chem. Eng. J. 2011, 169, 68-77. [CrossRef]

137. Perumal, E.; Paul, V.; Govindarajan, V.; Panneerselvam, L. A brief review on experimental fluorosis. Toxicol. Lett. 2013, 223, 236-251. [CrossRef]

138. Xiong, X.; Liu, J.; He, W.; Xia, T.; He, P.; Chen, X.; Yang, K.; Wang, A. Dose-effect relationship between drinking water fluoride levels and damage to liver and kidney functions in children. Environ. Res. 2007, 103, 112-116. [CrossRef]

139. Bhatnagar, M.; Rao, P.; Saxena, A.; Bhatnagar, R.; Meena, P.; Barbar, S.; Chouhan, A.; Vimal, S. Biochemical changes in brain and other tissues of young adult female mice from fluoride in their drinking water. Fluoride 2006, 39, 280-284.

140. Vani, M.L.; Reddy, K.P. Effects of fluoride accumulation on some enzymes of brain and gastrocnemius muscle of mice. Fluoride 2000, 33, 17-26.

141. Ghosh, A.; Mukherjee, K.; Ghosh, S.K.; Saha, B. Sources and toxicity of fluoride in the environment. Res. Chem. Intermed. 2013, 39, 2881-2915. [CrossRef]

142. Kabir, H.; Gupta, A.K.; Tripathy, S. Fluoride and human health: Systematic appraisal of sources, exposures, metabolism, and toxicity. Crit. Rev. Environ. Sci. Technol. 2020, 50, 1116-1193. [CrossRef]

143. Bouaziz, H.; Ammar, E.; Ghorbel, H.; Ketata, S.; Jamoussi, K.; Ayadi, F.; Guermazi, F.; Zeghal, N. Effect of fluoride ingested by lactating mice on the thyroid function and bone maturation of their suckling pups. Fluoride 2004, 37, 133-142.

144. Cinar, A.; Selcuk, M. Effects of chronic fluorosis on thyroxine, triiodothyronine, and protein-bound iodine in cows. Fluoride 2005, $38,65-68$. 
145. Rahman, M.M.A.; Fetouh, F.A. Effect of sodium fluoride on the thyroid follicular cells and the amelioration by calcium supplementation in Albino rats: A light and an electron microscopic study. J. Am. Sci. 2013, 9, 107-114.

146. Dehbandi, R.; Moore, F.; Keshavarzi, B. Geochemical sources, hydrogeochemical behavior, and health risk assessment of fluoride in an endemic fluorosis area, central Iran. Chemosphere 2018, 193, 763-776. [CrossRef] [PubMed]

147. Jia, H.; Qian, H.; Qu, W.; Zheng, L.; Feng, W.; Ren, W. Fluoride occurrence and human health risk in drinking water wells from southern edge of Chinese Loess Plateau. Int. J. Environ. Res. Public Health 2019, 16, 1683. [CrossRef] [PubMed]

148. Shi, M.; Gao, Z.; Feng, J.; Zhang, H.; Cui, Y.; Fang, S.; Liu, J. Characteristics and effects of fluorine release from shallow high-fluoride soils. Environ. Earth Sci. 2019, 78, 1-10. [CrossRef]

149. Adimalla, N.; Li, P. Occurrence, health risks, and geochemical mechanisms of fluoride and nitrate in groundwater of the rock-dominant semi-arid region, Telangana State, India. Hum. Ecol. Risk Assess. Int. J. 2019, 25, 81-103. [CrossRef]

150. Kumar, P.S. Fluoride in Groundwater-Sources, Geochemical Mobilization and Treatment Options. Int. J. Environ. Sci. Nat. Resour. 2017, 1, 106-108. [CrossRef]

151. Batabyal, A.K. Hydrogeochemical processes and contaminants enrichment with special emphasis on fluoride in groundwater of Birbhum district, West Bengal, India. Environ. Earth Sci. 2017, 76, 285. [CrossRef]

152. Biglari, H.; Chavoshani, A.; Javan, N.; Hossein Mahvi, A. Geochemical study of groundwater conditions with special emphasis on fluoride concentration, Iran. Desalination Water Treat. 2016, 57, 22392-22399. [CrossRef]

153. Brindha, K.; Jagadeshan, G.; Kalpana, L.; Elango, L. Fluoride in weathered rock aquifers of southern India: Managed aquifer recharge for mitigation. Environ. Sci. Pollut. Res. 2016, 23, 8302-8316. [CrossRef]

154. Özmen, Ö.; Koç, Ş.; Çelik, M. Evaluation of groundwater quality and contamination around fluorite mineralization, Kaman region, Central Anatolia, Turkey. Geochem. Int. 2011, 49, 76-89. [CrossRef]

155. Dibal, H.; Dajilak, W.; Lekmang, I.; Nimze, L.; Yenne, E. Seasonal variation in fluoride content in groundwaters of Langtang area, Northcentral Nigeria. Contemp. Trends Geosci. 2017, 6, 11-27. [CrossRef]

156. Das, K.; Dey, U.; Mondal, N.K. Deleneation of groundwater quality in the presence of fluoride in selected villages of Simlapal block, Bankura district, West Bengal, India. Sustain. Water Resour. Manag. 2016, 2, 439-451. [CrossRef]

157. Rukah, Y.A.; Alsokhny, K. Geochemical assessment of groundwater contamination with special emphasis on fluoride concentration, North Jordan. Geochemistry 2004, 64, 171-181. [CrossRef]

158. Adimalla, N. Assessment and mechanism of fluoride enrichment in groundwater from the hard rock terrain: A multivariate statistical approach. Geochem. Int. 2020, 58, 456-471. [CrossRef]

159. Zakaria, N.; Anornu, G.; Adomako, D.; Owusu-Nimo, F.; Gibrilla, A. Evolution of groundwater hydrogeochemistry and assessment of groundwater quality in the Anayari catchment. Groundw. Sustain. Dev. 2021, 12, 100489. [CrossRef]

160. Dibal, H.; Schoeneich, K.; Lar, U.; Garba, I.; Lekmang, I.; Daspan, R. Hydrogeochemical appraisal of fluoride in groundwater of Langtang area, Plateau State, Nigeria. Glob. J. Geol. Sci. 2016, 14, 23-39. [CrossRef]

161. Kumar, P.S.; Jose, A.; James, E. Spatial and seasonal variation in groundwater quality in parts of Cuddalore District, South India. Natl. Acad. Sci. Lett. 2013, 36, 167-179. [CrossRef]

162. Chen, Q.; Lu, Q.; Song, Z.; Chen, P.; Cui, Y.; Zhang, R.; Li, X.; Liu, J. The levels of fluorine in the sediments of the aquifer and their significance for fluorosis in coastal region of Laizhou Bay, China. Environ. Earth Sci. 2014, 71, 4513-4522. [CrossRef]

163. Abdelgawad, A.M.; Watanabe, K.; Takeuchi, S. Water-rock interaction study on the occurrence of fluoride-rich groundwater at Mizunami area, Japan. Environ. Asia 2009, 2, 20-29.

164. Fuoco, I.; Apollaro, C.; Criscuoli, A.; De Rosa, R.; Velizarov, S.; Figoli, A. Fluoride Polluted Groundwaters in Calabria Region (Southern Italy): Natural Source and Remediation. Water 2021, 13, 1626. [CrossRef]

165. Gogoi, R.R.; Khanikar, L.; Gogoi, J.; Neog, N.; Deka, D.J.; Sarma, K.P. Geochemical sources, hydrogeochemical behaviour of fluoride release and its health risk assessment in some fluorosis endemic areas of the Brahmaputra valley of Assam, India. Appl. Geochem. 2021, 127, 104911. [CrossRef]

166. Hurtado, R.; Gardea-Torresdey, J. Environmental evaluation of fluoride in drinking water at "Los altos de Jalisco," in the central Mexico region. J. Toxicol. Environ. Health Part A 2004, 67, 1741-1753. [CrossRef]

167. Sobsey, M.D.; Stauber, C.E.; Casanova, L.M.; Brown, J.M.; Elliott, M.A. Point of use household drinking water filtration: A practical, effective solution for providing sustained access to safe drinking water in the developing world. Environ. Sci. Technol. 2008, 42, 4261-4267. [CrossRef]

168. McGuigan, K.G.; Conroy, R.M.; Mosler, H.-J.; du Preez, M.; Ubomba-Jaswa, E.; Fernandez-Ibanez, P. Solar water disinfection (SODIS): A review from bench-top to roof-top. J. Hazard. Mater. 2012, 235, 29-46. [CrossRef]

169. Liu, X.; Wang, B.; Zheng, B. Geochemical process of fluorine in soil. Chin. J. Geochem. 2014, 33, 277-279. [CrossRef]

170. Berger, T.; Mathurin, F.A.; Drake, H.; Åström, M.E. Fluoride abundance and controls in fresh groundwater in Quaternary deposits and bedrock fractures in an area with fluorine-rich granitoid rocks. Sci. Total Environ. 2016, 569, 948-960. [CrossRef] [PubMed]

171. Shu, W.; Zhang, Z.; Lan, C.; Wong, M.H. Fluoride and aluminium concentrations of tea plants and tea products from Sichuan Province, PR China. Chemosphere 2003, 52, 1475-1482. [CrossRef]

172. Viero, A.; Roisenberg, C.; Roisenberg, A.; Vigo, A. The origin of fluoride in the granitic aquifer of Porto Alegre, Southern Brazil. Environ. Geol. 2009, 56, 1707-1719. [CrossRef]

173. Wenzel, W.W.; Blum, W.E. Fluorine speciation and mobility in F-contaminated soils. Soil Sci. 1992, 153, 357-364. [CrossRef] 
174. Cronin, S.; Manoharan, V.; Hedley, M.; Loganathan, P. Fluoride: A review of its fate, bioavailability, and risks of fluorosis in grazed-pasture systems in New Zealand. N. Z. J. Agric. Res. 2000, 43, 295-321. [CrossRef]

175. Yi, X.; Qiao, S.; Ma, L.; Wang, J.; Ruan, J. Soil fluoride fractions and their bioavailability to tea plants (Camellia sinensis L.). Environ. Geochem. Health 2017, 39, 1005-1016. [CrossRef]

176. Fuhong, R.; Shuqin, J. Distribution and formation of high-fluorine groundwater in China. Environ. Geol. Water Sci. 1988, 12, 3-10. [CrossRef]

177. Loganathan, P.; Gray, C.; Hedley, M.; Roberts, A. Total and soluble fluorine concentrations in relation to properties of soils in New Zealand. Eur. J. Soil Sci. 2006, 57, 411-421. [CrossRef]

178. Tylenda, C.A. Toxicological Profile for Fluorides, Hydrogen Fluoride, and Fluorine; Agency for Toxic Substances and Disease Registry: Atlanta, GA, USA, 2003.

179. Edmunds, W.; Smedley, P. Fluoride in Natural Waters; Selinus, O., Alloway, B., Centeno, J.A., Finkelman, R.B., Fuge, R., Lundh, U., Smedley, P., Eds.; Elsevier: Amsterdam, The Netherlands, 2005.

180. Gilpin, L.; Johnson, A.H. Fluorine in agricultural soils of southeastern Pennsylvania. Soil Sci. Soc. Am. J. 1980, 44, 255-258. [CrossRef]

181. Davison, A. Uptake, transport and accumulation of soil and airborne fluorides by vegetation. In Fluorides: Effects on Vegetation, Animals and Humans; Shupe, J., Peterson, H., Leone, N., Eds.; Paragon Press: Salt Lake City, UT, USA, 1983; pp. 61-82.

182. Abugri, D.; Pelig-Ba, K. Assessment of fluoride content in tropical surface soils used for crop cultivation. Afr. J. Environ. Sci. Technol. 2011, 5, 653-660. [CrossRef]

183. Jha, S.; Nayak, A.; Sharma, Y.; Mishra, V.; Sharma, D. Fluoride accumulation in soil and vegetation in the vicinity of brick fields. Bull. Environ. Contam. Toxicol. 2008, 80, 369-373. [CrossRef]

184. Moirana, R.L.; Mkunda, J.; Perez, M.P.; Machunda, R.; Mtei, K. The Influence of Fertilizers on the Behavior of Fluoride Fractions in the Alkaline Soil. J. Fluor. Chem. 2021, 250, 109883. [CrossRef]

185. Álvarez-Ayuso, E.; Giménez, A.; Ballesteros, J. Fluoride accumulation by plants grown in acid soils amended with flue gas desulphurisation gypsum. J. Hazard. Mater. 2011, 192, 1659-1666. [CrossRef]

186. Larsen, S.; Widdowson, A. Soil fluorine. J. Soil Sci. 1971, 22, 210-221. [CrossRef]

187. Guo, Q.; Wang, Y.; Ma, T.; Ma, R. Geochemical processes controlling the elevated fluoride concentrations in groundwaters of the Taiyuan Basin, Northern China. J. Geochem. Explor. 2007, 93, 1-12. [CrossRef]

188. Jeong, S.; Kim, D.; Yoon, H.-O. Stabilization of fluorine in soil using calcium hydroxide and its potential human health risk. Environ. Eng. Res. 2019, 24, 654-661. [CrossRef]

189. Gan, C.-D.; Jia, Y.-B.; Yang, J.-Y. Remediation of fluoride contaminated soil with nano-hydroxyapatite amendment: Response of soil fluoride bioavailability and microbial communities. J. Hazard. Mater. 2021, 405, 124694. [CrossRef] [PubMed]

190. Zhang, L.; Li, Q.; Ma, L.; Ruan, J. Characterization of fluoride uptake by roots of tea plants (Camellia sinensis (L.) O. Kuntze). Plant Soil 2013, 366, 659-669. [CrossRef]

191. Gadi, B.; Kumar, R.; Goswami, B.; Rankawat, R.; Rao, S.R. Recent developments in understanding fluoride accumulation, toxicity, and tolerance mechanisms in plants: An overview. J. Soil Sci. Plant Nutr. 2021, 21, 209-228. [CrossRef]

192. Anshumali, B. Fluoride in agricultural soil: A review on its sources and toxicity to plants. Glob. Sustain. Transit. Impacts Innov. 2014, 3, 29-37.

193. Smolik, B.; Telesiński, A.; Szymczak, J.; Zakrzewska, H. Assessing of humus usefulness in limiting of soluble fluoride content in soil. Environ. Prot. Nat. Resour. 2011, 49, 202-208.

194. Davison, A.; Takmaz-Nisancioglu, S.; Bailey, I. The Dynamics of Fluoride Accumulation by Vegetation Fluoride Toxicity; International Society for Fluoride Research: New Delhi, India, 1985; Volume 46.

195. Sharma, R.; Kaur, R. Insights into fluoride-induced oxidative stress and antioxidant defences in plants. Acta Physiol. Plant. 2018, 40, 1-14. [CrossRef]

196. Sahariya, A.; Bharadwaj, C.; Emmanuel, I.; Alam, A. Fluoride toxicity in soil and plants: An overview. Asian J. Adv. Res. 2021, 26-34.

197. Arnesen, A. Availability of fluoride to plants grown in contaminated soils. Plant Soil 1997, 191, 13-25. [CrossRef]

198. Panda, D. Fluoride toxicity stress: Physiological and biochemical consequences on plants. Int. J. Biores. Environ. Agric. Sci. 2015, 1, 70-84.

199. Gupta, S.; Banerjee, S.; Mondal, S. Phytotoxicity of fluoride in the germination of paddy (Oryza sativa) and its effect on the physiology and biochemistry of germinated seedlings. Fluoride 2009, 42, 142-146.

200. Baunthiyal, M.; Ranghar, S. Physiological and biochemical responses of plants under fluoride stress: An overview. Fluoride 2014, 47, 287-293.

201. Zuo, H.; Chen, L.; Kong, M.; Qiu, L.; Lü, P.; Wu, P.; Yang, Y.; Chen, K. Toxic effects of fluoride on organisms. Life Sci. 2018, 198, 18-24. [CrossRef]

202. Yadu, B.; Chandrakar, V.; Meena, R.K.; Poddar, A.; Keshavkant, S. Spermidine and Melatonin Attenuate Fluoride Toxicity by Regulating Gene Expression of Antioxidants in Cajanus cajan L. J. Plant Growth Regul. 2018, 37, 1113-1126. [CrossRef]

203. Singh, A.; Roychoudhury, A. Silicon-regulated antioxidant and osmolyte defense and methylglyoxal detoxification functions co-ordinately in attenuating fluoride toxicity and conferring protection to rice seedlings. Plant Physiol. Biochem. 2020, 154, 758-769. [CrossRef] 
204. Ahmad, M.A.; Bibi, H.; Munir, I.; Ahmad, M.N.; Zia, A.; Mustafa, G.; Ullah, I.; Khan, I. Fluoride toxicity and its effect on two varieties of Solanum lycopersicum. Fluoride 2018, 51, 267-277.

205. Banerjee, A.; Samanta, S.; Roychoudhury, A. Spermine ameliorates prolonged fluoride toxicity in soil-grown rice seedlings by activating the antioxidant machinery and glyoxalase system. Ecotoxicol. Environ. Saf. 2020, 189, 109737. [CrossRef]

206. Banerjee, A.; Roychoudhury, A. Differential regulation of defence pathways in aromatic and non-aromatic indica rice cultivars towards fluoride toxicity. Plant Cell Rep. 2019, 38, 1217-1233. [CrossRef] [PubMed]

207. Singh, A.; Roychoudhury, A. Salicylic acid-mediated alleviation of fluoride toxicity in rice by restricting fluoride bioaccumulation and strengthening the osmolyte, antioxidant and glyoxalase systems. Environ. Sci. Pollut. Res. 2021, 1-13. [CrossRef] [PubMed]

208. Banerjee, A.; Roychoudhury, A. Fluorine: A biohazardous agent for plants and phytoremediation strategies for its removal from the environment. Biol Plant 2019, 63, 104-112. [CrossRef]

209. Choudhary, S.; Rani, M.; Devika, O.S.; Patra, A.; Singh, R.K.; Prasad, S.K. Impact of fluoride on agriculture: A review on it's sources, toxicity in plants and mitigation strategies. Int. J. Chem. Stud. 2019, 7, 1675-1680.

210. Kumar, K.; Giri, A.; Vivek, P.; Kalaiyarasan, T.; Kumar, B. Effects of fluoride on respiration and photosynthesis in plants: An overview. Ann. Environ. Sci. Toxicol. 2017, 2, 043-047. [CrossRef]

211. Mondal, N.K. Effect of fluoride on photosynthesis, growth and accumulation of four widely cultivated rice (Oryza sativa L.) varieties in India. Ecotoxicol. Environ. Saf. 2017, 144, 36-44. [CrossRef]

212. Pelc, J.; Śnioszek, M.; Wróbel, J.; Telesiński, A. Effect of Fluoride on Germination, Early Growth and Antioxidant Enzymes Activity of Three Winter Wheat (Triticum aestivum L.) Cultivars. Appl. Sci. 2020, 10, 6971. [CrossRef]

213. Baunthiyal, M.; Ranghar, S. Accumulation of fluoride by plants: Potential for phytoremediation. Clean Soil Air Water 2015, 43, 127-132. [CrossRef]

214. Rizzu, M.; Tanda, A.; Cappai, C.; Roggero, P.P.; Seddaiu, G. Impacts of soil and water fluoride contamination on the safety and productivity of food and feed crops: A systematic review. Sci. Total Environ. 2021, 147650. [CrossRef]

215. Zouari, M.; Elloumi, N.; Bellassoued, K.; Ahmed, C.B.; Krayem, M.; Delmail, D.; Elfeki, A.; Rouina, B.B.; Abdallah, F.B.; Labrousse, P. Enzymatic antioxidant responses and mineral status in roots and leaves of olive plants subjected to fluoride stress. S. Afr. J. Bot. 2017, 111, 44-49. [CrossRef]

216. Elloumi, N.; Zouari, M.; Mezghani, I.; Abdallah, F.B.; Woodward, S.; Kallel, M. Adaptive biochemical and physiological responses of Eriobotrya japonica to fluoride air pollution. Ecotoxicology 2017, 26, 991-1001. [CrossRef]

217. Ali, S.A.R.; Ansari, M.; Ahmad, M.N.; Haider, A.; Jabeen, F.; Zulfiqar, A. Effect of sodium fluoride stress on the productivity of Solanum Melongenal L. (Aubergine, Brinjal, Eggplant). Fluoride 2020, 53, 521-530.

218. Peng, C.Y.; Xu, X.F.; Ren, Y.F.; Niu, H.L.; Yang, Y.Q.; Hou, R.Y.; Wan, X.C.; Cai, H.M. Fluoride absorption, transportation and tolerance mechanism in Camellia sinensis, and its bioavailability and health risk assessment: A systematic review. J. Sci. Food Agric. 2021, 101, 379-387. [CrossRef]

219. Jackson, R.D.; Brizendine, E.J.; Kelly, S.A.; Hinesley, R.; Stookey, G.K.; Dunipace, A.J. The fluoride content of foods and beverages from negligibly and optimally fluoridated communities. Community Dent. Oral Epidemiol. 2002, 30, 382-391. [CrossRef]

220. Singer, L.; Ophaug, R.; Harland, B. Fluoride intake of young male adults in the United States. Am. J. Clin. Nutr. 1980, 33, 328-332. [CrossRef]

221. Lu, Y.; Guo, W.-F.; Yang, X.-Q. Fluoride content in tea and its relationship with tea quality. J. Agric. Food Chem. 2004, 52, $4472-4476$. [CrossRef] [PubMed]

222. Banerjee, A.; Roychoudhury, A. Melatonin application reduces fluoride uptake and toxicity in rice seedlings by altering abscisic acid, gibberellin, auxin and antioxidant homeostasis. Plant Physiol. Biochem. 2019, 145, 164-173. [CrossRef] [PubMed]

223. Singh, A.; Banerjee, A.; Roychoudhury, A. Seed priming with calcium compounds abrogate fluoride-induced oxidative stress by upregulating defence pathways in an indica rice variety. Protoplasma 2020, 257, 767-782. [CrossRef] [PubMed]

224. Singh, A.; Banerjee, A.; Roychoudhury, A. Differential responses of Vigna radiata and Vigna mungo to fluoride-induced oxidative stress and amelioration via exogenous application of sodium nitroprusside. J. Plant Growth Regul. 2021, 1-16. [CrossRef]

225. Ghassemi-Golezani, K.; Farhangi-Abriz, S. Biochar alleviates fluoride toxicity and oxidative stress in safflower (Carthamus tinctorius L.) seedlings. Chemosphere 2019, 223, 406-415. [CrossRef]

226. Kalyani, G.; Rao, G.B.; Vijaya, B.; Kumar, Y.P. Biosorption isotherms of fluoride from aqueous solution on Ulva fasciata sp.-A waste material. Int. J. Appl. Environ. Sci. 2009, 4, 173-182.

227. Banerjee, G.; Sengupta, A.; Roy, T.; Banerjee, P.P.; Chattopadhyay, A.; Ray, A.K. Isolation and characterization of fluoride resistant bacterial strains from fluoride endemic areas of west Bengal, India: Assessment of their fluoride absorption efficiency. Fluoride 2016, 49, 429.

228. Mukherjee, S.; Yadav, V.; Mondal, M.; Banerjee, S.; Halder, G. Characterization of a fluoride-resistant bacterium Acinetobacter sp. RH5 towards assessment of its water defluoridation capability. Appl. Water Sci. 2017, 7, 1923-1930. [CrossRef]

229. Mukherjee, S.; Sahu, P.; Halder, G. Comparative assessment of the fluoride removal capability of immobilized and dead cells of Staphylococcus lentus (KX941098) isolated from contaminated groundwater. Environ. Prog. Sustain. Energy 2018, 37, 1573-1586. [CrossRef]

230. Dwivedi, S.; Mondal, P.; Balomajumder, C. Bioremoval of Fluoride from Synthetic Water Using Gram-Negative Bacteria Shewanella putrefaciens. J. Hazard. Toxic Radioact. Waste 2017, 21, 04016023. [CrossRef] 
231. Pal, K.C.; Mondal, N.K.; Chatterjee, S.; Ghosh, T.S.; Datta, J.K. Characterization of fluoride-tolerant halophilic Bacillus flexus NM25 (HQ875778) isolated from fluoride-affected soil in Birbhum District, West Bengal, India. Environ. Monit. Assess. 2014, 186, 699-709. [CrossRef]

232. Su, J.F.; Wu, Z.Z.; Huang, T.L.; Zhang, H.; Li, J.W. A new technology for simultaneous calcium-nitrate and fluoride removal in the biofilm reactor. J. Hazard. Mater. 2020, 399, 122846. [CrossRef] [PubMed]

233. Bhatnagar, M.; Bhatnagar, A.; Jha, S. Interactive biosorption by microalgal biomass as a tool for fluoride removal. Biotechnol. Lett. 2002, 24, 1079-1081. [CrossRef]

234. Venkata Mohan, S.; Ramanaiah, S.V.; Rajkumar, B.; Sarma, P.N. Biosorption of fluoride from aqueous phase onto algal Spirogyra IO1 and evaluation of adsorption kinetics. Bioresour. Technol. 2007, 98, 1006-1011. [CrossRef] [PubMed]

235. Venkata Mohan, S.; Ramanaiah, S.V.; Rajkumar, B.; Sarma, P.N. Removal of fluoride from aqueous phase by biosorption onto algal biosorbent Spirogyra sp.-IO2: Sorption mechanism elucidation. J. Hazard. Mater. 2007, 141, 465-474. [CrossRef] [PubMed]

236. Mukherjee, S.; Mondal, M.; Banerjee, S.; Halder, G. Elucidation of the sorptive uptake of fluoride by Ca2+-treated and untreated algal biomass of Nostoc sp. (BTA394): Isotherm, kinetics, thermodynamics and safe disposal. Process Saf. Environ. Prot. 2017, 107, 334-345. [CrossRef]

237. Mittal, Y.; Srivastava, P.; Kumar, N.; Yadav, A.K. Remediation of fluoride contaminated water using encapsulated active growing blue-green algae, Phormidium sp. Environ. Technol. Innov. 2020, 19, 100855. [CrossRef]

238. Mohamed, W.S.E.-D.; Hamad, M.T.M.H.; Kamel, M.Z. Application of statistical response surface methodology for optimization of fluoride removal efficiency by Padina sp. alga. Water Environ. Res. 2020, 92, 1080-1088. [CrossRef] [PubMed]

239. Ramanaiah, S.V.; Venkata Mohan, S.; Sarma, P.N. Adsorptive removal of fluoride from aqueous phase using waste fungus (Pleurotus ostreatus 1804) biosorbent: Kinetics evaluation. Ecol. Eng. 2007, 31, 47-56. [CrossRef]

240. Prajapat, R.; Bhatnagar, A.; Gaur, R.K.; Bajpai, V. Fluoride removal from water by sorbing on plant and fungal biomass. Int. J. Biol. Technol. 2010, 1, 43-46.

241. Amin, F.; Talpur, F.N.; Balouch, A.; Surhio, M.A.; Bhutto, M.A. Biosorption of fluoride from aqueous solution by white-rot fungus Pleurotus eryngii ATCC 90888. Environ. Nanotechnol. Monit. Manag. 2015, 3, 30-37. [CrossRef]

242. Liao, Y.; Brandt, B.W.; Li, J.; Crielaard, W.; Van Loveren, C.; Deng, D.M. Fluoride resistance in Streptococcus mutans: A mini review. J. Oral Microbiol. 2017, 9, 1344509. [CrossRef]

243. Katiyar, P.; Pandey, N.; Sahu, K.K. Biological approaches of fluoride remediation: Potential for environmental clean-up. Environ. Sci. Pollut. Res. 2020, 27, 13044-13055. [CrossRef]

244. van Loveren, C.; Hoogenkamp, M.A.; Deng, D.M.; ten Cate, J.M. Effects of Different Kinds of Fluorides on Enolase and ATPase Activity of a Fluoride-Sensitive and Fluoride-Resistant Streptococcus mutans Strain. Caries Res. 2008, 42, 429-434. [CrossRef]

245. Qu, Y.; Zhang, X.; Xu, J.; Zhang, W.; Guo, Y. Removal of hexavalent chromium from wastewater using magnetotactic bacteria. Sep. Purif. Technol. 2014, 136, 10-17. [CrossRef]

246. Zakaria, Z.A.; Zakaria, Z.; Surif, S.; Ahmad, W.A. Hexavalent chromium reduction by Acinetobacter haemolyticus isolated from heavy-metal contaminated wastewater. J. Hazard. Mater. 2007, 146, 30-38. [CrossRef]

247. Huang, M.-S.; Pan, J.; Zheng, L.-P. Removal of heavy metals from aqueous solutions using bacteria. J. Shanghai Univ. 2001, 5, 253-259. [CrossRef]

248. Sone, Y.; Mochizuki, Y.; Koizawa, K.; Nakamura, R.; Pan-Hou, H.; Itoh, T.; Kiyono, M. Mercurial-resistance determinants in Pseudomonas strain K-62 plasmid pMR68. AMB Express 2013, 3, 41. [CrossRef]

249. Abo-Amer, A.E.; Ramadan, A.B.; Abo-State, M.; Abu-Gharbia, M.A.; Ahmed, H.E. Biosorption of aluminum, cobalt, and copper ions by Providencia rettgeri isolated from wastewater. J. Basic Microbiol. 2013, 53, 477-488. [CrossRef] [PubMed]

250. Wang, J.; Zhao, F.-J.; Meharg, A.A.; Raab, A.; Feldmann, J.; McGrath, S.P. Mechanisms of Arsenic Hyperaccumulation in Pteris vittata. Uptake Kinetics, Interactions with Phosphate, and Arsenic Speciation. Plant Physiol. 2002, 130, 1552-1561. [CrossRef]

251. Weerasooriyagedara, M.; Ashiq, A.; Rajapaksha, A.U.; Wanigathunge, R.P.; Agarwal, T.; Magana-Arachchi, D.; Vithanage, M. Phytoremediation of fluoride from the environmental matrices: A review on its application strategies. Groundw. Sustain. Dev. 2020, 10, 100349. [CrossRef]

252. Sharma, R.; Sharma, R.; Parveen, K.; Pant, D.; Malaviya, P. Comprehensive and critical appraisal of plant-based defluoridation from environmental matrices. Chemosphere 2021, 281, 130892. [CrossRef] [PubMed]

253. Chen, L.; Xiong, Z. Phytoremediation in fluoride contaminated water and toxicity of fluoride on plants. Environ. Sci. Technol. 2011, 34, 60-151.

254. Khandare, R.V.; Desai, S.B.; Bhujbal, S.S.; Watharkar, A.D.; Biradar, S.P.; Pawar, P.K.; Govindwar, S.P. Phytoremediation of fluoride with garden ornamentals Nerium oleander, Portulaca oleracea, and Pogonatherum crinitum. Environ. Sci. Pollut. Res. 2017, 24, 6833-6839. [CrossRef]

255. Bayu, K.; Geremew, A.; Deriba, W.; Mulugeta, Y.; Wagari, S.; Dirirsa, G. Fluoride removal efficiency of Tulsi (Ocimum Sanctum) from water. Water Supply 2021. [CrossRef]

256. Khandare, R.V.; Watharkar, A.D.; Pawar, P.K.; Jagtap, A.A.; Desai, N.S. Hydrophytic plants Canna indica, Epipremnum aureum, Cyperus alternifolius and Cyperus rotundus for phytoremediation of fluoride from water. Environ. Technol. Innov. 2021, 21, 101234. [CrossRef]

257. Braga, A.F.; Borges, A.C.; Vaz, L.R.; Souza, T.D.D.; Rosa, A.P. Phytoremediation of Fluoride-contaminated Water by Landoltia punctata. Eng. Agric. 2021, 41, 171-180. [CrossRef] 
258. del Socorro Santos-Díaz, M.; Zamora-Pedraza, C. Fluoride removal from water by plant species that are tolerant and highly tolerant to hydrogen fluoride. Fluoride 2010, 43, 150-156.

259. Karmakar, S.; Mukherjee, J.; Mukherjee, S. Removal of fluoride contamination in water by three aquatic plants. Int. J. Phytoremediation 2016, 18, 222-227. [CrossRef]

260. Zhang, Y.; Huang, K. Grape pomace as a biosorbent for fluoride removal from groundwater. RSC Adv. 2019, 9, 7767-7776. [CrossRef]

261. Deshmukh, M.A.; Dodamani, A.S.; Karibasappa, G.N.; Khairnar, M.R.; Naik, R.G.; Jadhav, H.C. Tea ash-a new medium for water defluoridation. Indian J. Public Health 2018, 9, 153. [CrossRef]

262. Deshmukh, W.S.; Attar, S.; Waghmare, M. Investigation on sorption of fluoride in water using rice husk as an adsorbent. Nat. Environ. Pollut. Technol. 2009, 8, 217-223.

263. Murugan, M.; Subramanian, E. Studies on defluoridation of water by Tamarind seed, an unconventional biosorbent. J. Water Health 2006, 4, 453-461. [CrossRef]

264. Srinivasulu, D. Senna auriculata L. flower petal biomass: An alternative green biosorbent for the removal of fluoride from aqueous solutions. Acta Ecol. Sin. 2021, in press. [CrossRef]

265. Suneetha, M.; Sundar, B.S.; Ravindhranath, K. Removal of fluoride from polluted waters using active carbon derived from barks of Vitex negundo plant. J. Anal. Sci. Technol. 2015, 6, 1-19. [CrossRef]

266. George, A.M.; Tembhurkar, A. Biosorptive removal of fluoride from aqueous solution onto newly developed biosorbent from Ficus benghalensis leaf: Evaluation of equilibrium, kinetics, and thermodynamics. Sustain. Chem. Pharm. 2018, 10, 125-133. [CrossRef]

267. Sahu, N.; Bhan, C.; Singh, J.; Sahu, N.; Bhan, C.; Singh, J. Removal of fluoride from an aqueous solution by batch and column process using activated carbon derived from iron infused Pisum sativum peel: Characterization, Isotherm, kinetics study. Environ. Eng. Res. 2020, 26, 200241. [CrossRef]

268. Ravulapalli, S.; Kunta, R. Defluoridation studies using active carbon derived from the barks of Ficus racemosa plant. J. Fluor. Chem. 2017, 193, 58-66. [CrossRef]

269. George, A.; Tembhurkar, A. Taguchi experimental design for adsorptive removal of fluoride from water using novel Ficus glomerata Bark-developed biosorbent. Int. J. Environ. Sci. Technol. 2020, 17, 4829-4840. [CrossRef]

270. Angelin, A.; Kalpana, M.; Govindan, K.; Kavitha, S. Characterizations and fluoride adsorption performance of wattle humus biosorbent. Environ. Sci. Pollut. Res. 2021, 1-14. [CrossRef] [PubMed]

271. Siaurusevičiūte, I.; Albrektienè, R. Removal of Fluorides from Aqueous Solutions Using Exhausted Coffee Grounds and Iron Sludge. Water 2021, 13, 1512. [CrossRef]

272. Mondal, N.K.; Bhaumik, R.; Dey, U.; Pal, K.C.; Das, C.; Maitra, A.; Datta, J.K. Fluoride remediation using floating macrophytes. Commun Plant Sci 2014, 4, 23-33.

273. Yadav, A.K.; Abbassi, R.; Gupta, A.; Dadashzadeh, M. Removal of fluoride from aqueous solution and groundwater by wheat straw, sawdust and activated bagasse carbon of sugarcane. Ecol. Eng. 2013, 52, 211-218. [CrossRef]

274. Oswald William, J.; Gotaas Harold, B. Photosynthesis in Sewage Treatment. Trans. Am. Soc. Civ. Eng. 1957, 122, 73-97. [CrossRef]

275. Ramachandra, T.V.; Durga Madhab, M.; Shilpi, S.; Joshi, N.V. Algal biofuel from urban wastewater in India: Scope and challenges. Renew. Sustain. Energy Rev. 2013, 21,767-777. [CrossRef]

276. Ali, G. Fluoride and aluminium tolerance in planktonic microalgae. Fluoride 2004, 37, 88-95.

277. Bhatnagar, M.; Bhatnagar, A. Algal and cyanobacterial responses to fluoride. Fluoride 2000, 33, 55-65.

278. Bhatnagar, M.; Bhatnagar, A. Physiology of Anabaena khannae and Chlorococcum humicola under fluoride stress. Folia Microbiol. 2004, 49, 291-296. [CrossRef]

279. Davis, T.A.; Volesky, B.; Mucci, A. A review of the biochemistry of heavy metal biosorption by brown algae. Water Res. 2003, 37, 4311-4330. [CrossRef]

280. Dixit, R.; Malaviya, D.; Pandiyan, K.; Singh, U.B.; Sahu, A.; Shukla, R.; Singh, B.P.; Rai, J.P.; Sharma, P.K.; Lade, H. Bioremediation of heavy metals from soil and aquatic environment: An overview of principles and criteria of fundamental processes. Sustainability 2015, 7, 2189-2212. [CrossRef]

281. Singh, A.; Gothalwal, R. A reappraisal on biodegradation of fluoride compounds: Role of microbes. Water Environ. J. 2018, 32, 481-487. [CrossRef] 